This item was submitted to Loughborough's Research Repository by the author.

Items in Figshare are protected by copyright, with all rights reserved, unless otherwise indicated.

\title{
An index to track the ecological effects of drought development and recovery on riverine invertebrate communities
}

PLEASE CITE THE PUBLISHED VERSION

http://dx.doi.org/10.1016/j.ecolind.2017.06.058

\section{PUBLISHER}

(C) Elsevier

VERSION

AM (Accepted Manuscript)

\section{PUBLISHER STATEMENT}

This work is made available according to the conditions of the Creative Commons Attribution-NonCommercialNoDerivatives 4.0 International (CC BY-NC-ND 4.0) licence. Full details of this licence are available at: https://creativecommons.org/licenses/by-nc-nd/4.0/

\section{LICENCE}

CC BY-NC-ND 4.0

\section{REPOSITORY RECORD}

Chadd, Richard P., J. England, Drew Constable, Michael J. Dunbar, Chris A. Extence, David J. Leeming, John A. Murray-Bligh, and Paul J. Wood. 2019. "An Index to Track the Ecological Effects of Drought Development and Recovery on Riverine Invertebrate Communities". figshare. https://hdl.handle.net/2134/26053. 


\section{An index to track the ecological effects of drought development and recovery}

2 on riverine invertebrate communities.

3 RICHARD P. CHADD ${ }^{\mathrm{a}}$, JUDY A. ENGLAND ${ }^{\mathrm{b}}$, DREW CONSTABLE $^{\mathrm{c}}$, MICHAEL J. DUNBAR $^{\mathrm{d}}, \mathrm{CHRIS}$

4 A. EXTENCE ${ }^{a}$, DAVID J. LEEMING ${ }^{\mathrm{e}}$, JOHN A. MURRAY-BLIGH ${ }^{\mathrm{d}}$ and PAUL J. WOOD'.

5 a Environment Agency of England, Stepping Stone Walk, Winfrey Avenue, Spalding, Lincolnshire,

6 PE11 1DA, UK. (richard.chadd@environment-agency.gov.uk) - corresponding author

$7 \quad{ }^{b}$ Environment Agency of England, Apollo Court, 2, Bishops Square Business Park, St. Albans Road

8 West, Hatfield, Herts, AL10 9EX, UK. (judy.england@environment-agency.gov.uk)

$9{ }^{c}$ Environment Agency of England, Bromholme Lane, Brampton, Huntingdon, Cambridgeshire, PE28

10 4NE, UK. (andrew.constable@environment-agency.gov.uk)

11 dEnvironment Agency of England, Manley House, Kestrel Way, Exeter, EX2 7LQ, UK.

12 (mike.dunbar@environment-agency.gov.uk) (john.murray-bligh@environment-agency.gov.uk)

eDJL Ecologists, UK. (djlecologists@gmail.com)

'Loughborough University, Department of Geography, Centre for Hydrological and Ecosystem Science, Loughborough, UK. (p.j.wood@lboro.ac.uk)

\section{Abstract}

In rivers, the ecological effects of drought typically result in gradual adjustments of invertebrate community structure and functioning, punctuated by sudden changes as key habitats, such as wetted channel margins, become dewatered and dry. This paper outlines the development and application of a new index (Drought Effect of Habitat Loss on Invertebrates - DEHLI) to quantify the effects of drought on instream macroinvertebrate communities by assigning weights to taxa on the basis of their likely association with key stages of channel drying. Two case studies are presented, in which the DEHLI index illustrates the ecological development of drought conditions and subsequent recovery. These examples demonstrate persistent drought effects months or several years after river flows recovered. Results derived using DEHLI are compared with an established macroinvertebrate flow velocity-reactive index (Lotic-invertebrate Index for Flow Evaluation - LIFE score) and demonstrates its greater sensitivity to drought conditions. Data from a number of rivers in south east England were used to calibrate a statistical model, which was then used to examine the response of DEHLI and LIFE to a hypothetical multi-year drought. This demonstrated a difference in response between sampling seasons, with the spring model indicating a lagged response due to delayed recolonisation and the autumn model differentiating habitat loss and flow velocity-driven responses. The application of DEHLI and the principles which underlie it allow the effects of drought on instream habitats and invertebrates associated with short or long term weather patterns to be monitored, whilst also allowing the identification of specific locations where intervention via river restoration, or revision of existing abstraction licensing, may be required to increase resilience to the effect of anthropogenic activities exacerbated by climate change.

Key words

41 River; habitat; invertebrates; drought; index; disturbance

\section{1. Introduction}

Droughts have an important role in shaping lotic ecosystems (Extence 1981, Lake, 2011, Lu et al., 2016; Piniewski et al., In Press). A potential increase in extreme events associated with our changing climate suggests the frequency of droughts is likely to increase in many areas of the globe (Dai, 2011; Prudhomme et al., 2014). Some recent studies indicate that the magnitude and frequency of short 
47 duration drought events ( $<18$ months) will increase in the future in tandem with rises in flood 48 frequency (Ledger and Milner 2015; Watts and Anderson, 2013). While climate change is expected to 49 intensify drought in many regions, its short and long-term ecological effects are poorly understood 50 (Bogan et al. 2014; Van Loon et al., 2016).

51 Drought is a natural disturbance in rivers that influences community structure and functioning (Lu et 52 al., 2016), altering species composition, abundance and richness (Atkinson et al, 2014) and favouring on its duration and intensity, as well as antecedent conditions (Bogan et al, 2015; Chessman 2015 . Stubbington et al 2015). Lake (2003) distinguishes between regular seasonal and predictable droughts, as in Mediterranean regions, from supra-seasonal droughts which are usually unpredictable in nature and are associated with longer periods of drying across multiple seasons. Supra-seasonal droughts normally include one or more seasons typically associated with higher river flows. The distinction between different types of drought is important since the biota within rivers which experience regular seasonal channel drying typically display adaptions to such conditions (Boulton 2003; Bogan et al., 2015), whereas unpredictable supra-seasonal droughts have the potential to result in greater ecological effects due to their protracted nature (e.g. Wood and Armitage 2004). In addition, the antecedent conditions and timing of supra-seasonal droughts are important controls on the community effects (Dewson et al., 2007; Lake, 2011). The effects of a drought on river macroinvertebrate communities will vary according to the river type, in particular whether it is a groundwater or surface water-dominated river, the pattern of drying and degree of physical modification (see Lake, 2011 for review). More physically diverse river reaches, including those with marginal habitats or with variable water depth and flow-velocity, provide habitat heterogeneity to support a wider range of taxa. This physical heterogeneity is widely considered to result in populations and communities which are more resilient to extreme hydrological events by the provision of refugia which facilitate rapid recovery following disturbances (Townsend and Hildrew, 1994; Dunbar et al. 2010a; Dunbar et al. 2010b; Chester and Robson, 2011).

Drought disturbances typically exhibit a ramp pattern with the magnitude of effects growing with increasing duration of the event. Conditions during a drought may fluctuate, however, with brief rainfall events providing occasional inputs of water, but the magnitude of the drought steadily increases over time (ramps up) and often affects progressively greater spatial scales (Lake 2000; Parry et al., 2017). The response of the aquatic stages of lotic communities to drought is punctuated by significant step changes, as thresholds between critical water levels are crossed (Boulton, 2003; Boulton and Lake, 2008). The step-like nature of these changes, as thresholds are exceeded, result from the abrupt loss or fragmentation of habitats (e.g. riffle areas), alteration in physico-chemical conditions and the loss of lateral, longitudinal and/or vertical connectivity (Boulton, 2003; Boulton and Lake, 2008). The ability of biota to withstand a disturbance (resistance) and their subsequent capacity to re-colonise (resilience) reflect the availability of refugia in the channel and wider catchment (Lake 2000). Species and communities which possess strategies to survive low-flows, lentic conditions and drying, or are highly mobile, may be able to recolonize and recover rapidly after the cessation of drought conditions. The time taken to re-colonise, however, is typically taxon-specific and reflects the timing, intensity, and duration of individual drought events (Boulton, 2003; Boulton and Lake 2008).

There is a need to understand the ecological effects of high magnitude supra-seasonal drought events in order to anticipate the effects of climate change and help to balance the need for anthropogenic water supply, whilst maintaining the ecological integrity of river habitats (Wilby et al., 2010). There is also a growing recognition for the need for more robust and defensible data to address multiple issues related to water resources and environmental legislation, such as management of protected species and habitats and maintenance of ecological standards for healthy ecosystems enshrined in the European Community Habitats Directive and Water Framework Directive (WFD) (Acreman and Ferguson, 2010). To make use of these data we need tools and techniques to ascertain the influence of different environmental pressures. The need to assess the ecological 
97 effects of variations in river flow led to the development of the macroinvertebrate index: Lotic98 invertebrate Index for Flow Evaluation (LIFE; Extence et al, 1999). LIFE uses recognized flow 99 associations to weight invertebrate groups according to their preference for flow velocity. Existing 100 biological indices, such as LIFE in the UK, and others developed in Canada (Armanini et al., 2012), 101 Australia (Rose et al., 2008) and New Zealand (Caruso 2002), have been correlated with historic 102 hydrological conditions and hydraulic parameters (Extence et al 1999; Monk et al. 2008; Dunbar et al. 103 2010a, 2010b) with some degree of success. The relationship between the LIFE index and flow 104 volume (discharge) breaks down, however, under extreme low flow conditions (Monk et al. 2006) 105 possibly reflecting the ramp disturbance and threshold-crossing nature of drought pressures.

106 To address this deficiency, this study aimed to develop a new macroinvertebrate community-based metric, the Drought Effect of Habitat Loss on Invertebrates (DEHLI) index. This paper aims to outline the process of DEHLI calculation and to test its utility by using data from two case studies (involving monthly and annual sampling, respectively) and by undertaking a modelling exercise to test the drought response of both the DEHLI and LIFE indices to a hypothetical multi-year drought, calibrated to actual data from 114 samples. The index is based upon the concept outlined in Boulton and Lake (2008) linking the steps of the ramp disturbance with the sequential loss of aquatic invertebrates to changing abiotic and biotic conditions. It has initially been designed to be derived using data from the Environment Agencies of the United Kingdom, but could be readily adapted for use in any country or global region.

\section{Methods}

\section{$117 \quad 2.1$ Index structure}

118 The primary theoretical element of the ramp disturbance model of drought (sensu Lake 2000) is the 119 sequence of changes in hydrological connectivity and wetted habitat (Boulton 2003, Boulton and Lake 120 2008) as the drought progresses (see Figure 1). The gradual intensifying of drought conditions will 121 initially lead to a reduction in river flow (volume, depth and in some instances, velocity) severing 122 lateral connectivity to marginal riparian habitat (2) and subsequently longitudinal connectivity (3), as 123 topographic high points on the river bed are exposed. Ultimately, only isolated pools of water may 124 remain (4) and as the drought progresses these will continue to shrink until surface water is lost and 125 only moist sediments and subsurface water remains (5). Each stage of the ramp disturbance will 126 potentially be characterised by a loss of indicator taxa relating to a reduction in available habitat and 127 associated changes to abiotic parameters (e.g., water chemistry and flow velocity). 

as a drought progresses - adapted from Boulton, 2003.

131 A - river cross-section, B - longitudinal profile.

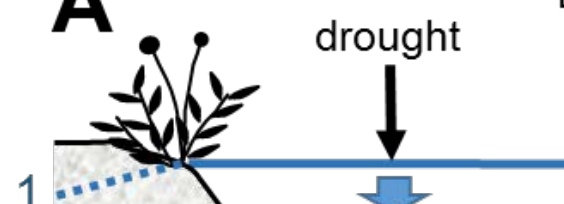

Decrease in flow

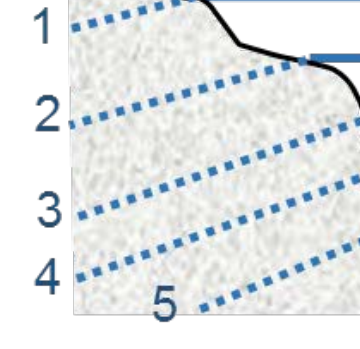

B

Loss of longitudinal connectivity

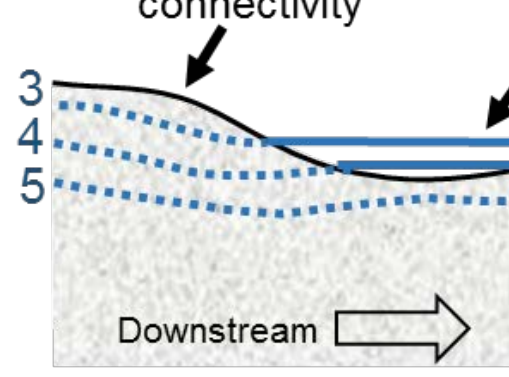

The Drought Effect of Habitat Loss on Invertebrates (DEHLI) index places the aquatic stages of invertebrate taxa into groups based on these sequential stages of habitat availability, according to the invertebrates' relative tolerance to the loss of suitable habitat at each stage.

As outlined in Boulton and Lake (2008), stage 1 is characterised by the presence of taxa which require very fast flowing water or cool, well-oxygenated flowing water for effective metabolism, in order to carry out feeding and processing of nutrients. Such conditions become less common when river discharge declines during the early stages of drought, with associated reductions in flow velocity beside reduction of turbulence. The relevant taxa lost at this stage are all families and genera of aquatic insects in the orders Ephemeroptera, Plecoptera and Trichoptera.

Taxa lost at stage 2 use stream-side vegetation for emergence, food, shelter and case-building material and/or are intimately associated with floodplains. The disconnection of marginal habitats effectively removes the necessary elements required for survival. Such taxa include, for example, Odonata or Lepidoptera.

As the river moves to stage 3 , taxa which not only require lotic water to respire effectively, but also some which need a current for provision of food (e.g. Hydropsychidae and Simuliidae), may be 
151 progressively lost as the river enters a fully lentic phase, resulting in a sharp decline in lotic taxon 152 richness. This loss is typically balanced by colonisation by lentic taxa, such as certain Hemiptera, 153 Coleoptera and Diptera which are physiologically and anatomically adapted to lentic-water 154 environments.

155 In stage 4, remaining pools of surface water contract with a resulting deterioration in water quality 156 (specifically, reducing dissolved oxygen and concentration of nutrients such as phosphate, and an 157 increase in water temperature). This results in a decline in lentic taxa which require relatively high 158 levels of oxygen, such as certain Odonata and Ephemeroptera, and favours those taxa which can 159 persist in relatively deoxygenated conditions, such as certain Coleoptera. Predation tends to intensify 160 in such environments as total habitat availability declines.

161 At stage 5, free surface water is lost completely, leaving only moist sediments and taxa which are 162 adapted to such conditions, e.g., by producing desiccation-resistant stages or being physiologically 163 adapted to obtain sufficient oxygen in moist sediments. Few aquatic invertebrates are capable of this, 164 with the exception of certain Gastropoda, Coleoptera and Diptera. Finally, the streambed becomes 165 completely desiccated and almost all aquatic invertebrates are lost, though some resting stages (such 166 as eggs) may remain.

167 Each taxon has, therefore, been assigned a Drought Intolerance Score (DIS) based on its association 168 with instream habitats which are lost as a drought intensifies, incorporating relative physiological 169 tolerance to drying and behavioural or life-history adaptation which avoids (or fails to avoid) loss of the 170 aquatic stage of the taxon from the river reach. Lower individual scores indicate a greater tolerance to 171 the prevailing conditions as the drought event becomes progressively more severe, while higher 172 scores indicate a greater sensitivity to changes in flow volume, flow velocity and associated habitat 173 characteristics (in practical terms, there is a lower tolerance to reduced water quality, flow velocity or 174 both). Scores were allocated using a combination of expert judgement, published sources of data on 175 taxon/habitat relationships (references are appended as supplementary material) and trait-based 176 databases such as www.freshwaterecology.info (Schmidt-Kloiber and Hering, 2015). The presentation 177 of taxa is arranged in each ecological group according to phylogenic convention to illustrate differing 178 responses among related orders and to facilitate calculation of the index (see Table 1). 
Table 1: Individual Drought Intolerance Score (DIS), by taxon. ( ${ }^{*}$ Taxa which can 181 tolerate more than one stage of drying. The taxa must not be double-counted).

\begin{tabular}{|c|c|c|}
\hline $\begin{array}{l}\text { HABITAT OR HABITAT CHANGE: ECOLOGICAL } \\
\text { GROUP }\end{array}$ & FAMILY (GENUS) & DIS \\
\hline \multirow{8}{*}{$\begin{array}{l}\text { Decrease in flow/volume: specialist torrenticoles } \\
\text { or need fast-flowing, well oxygenated water }\end{array}$} & Heptageniidae (E) & 10 \\
\hline & Ameletidae (E) & 10 \\
\hline & Perlidae $(\mathrm{P})$ & 10 \\
\hline & Chloroperlidae $(\mathrm{P})$ & 10 \\
\hline & $\begin{array}{l}\text { Taeniopterigidae (Brachyptera \& Rhabdiopteryx) } \\
(\mathrm{P})\end{array}$ & 9 \\
\hline & Philopotamidae (Philopotamus \& Wormaldia) ( $\mathrm{T}$ ) & 10 \\
\hline & Rhyacophilidae $(\mathrm{T})$ & 10 \\
\hline & Odontoceridae $(\mathrm{T})$ & 9 \\
\hline \multirow{14}{*}{$\begin{array}{l}\text { Loss of lateral connectivity: uses stream edge } \\
\text { habitats or vegetation }\end{array}$} & Hydrobiidae $(G)$ & 7 \\
\hline & Bithyniidae (G) & 7 \\
\hline & Valvatidae (G) & 7 \\
\hline & Platycnemididae $(\mathrm{O})$ & 7 \\
\hline & Lestidae $(\mathrm{O})$ & 7 \\
\hline & Calopterygidae (O) & 7 \\
\hline & Aeshnidae $(\mathrm{O})$ & 7 \\
\hline & Nepidae $(\mathrm{H})$ & 7 \\
\hline & Hydraenidae $(\mathrm{C})$ & 7 \\
\hline & Phryganeidae $(T)$ & 7 \\
\hline & Beraeidae $(\mathrm{T})$ & 7 \\
\hline & Pyralidae (L) & 7 \\
\hline & Thaumaleidae (D) & 8 \\
\hline & Dixidae (Primarily Dixella spp.) (D) & 8 \\
\hline \multirow{23}{*}{$\begin{array}{l}\text { Loss of longitudinal connectivity (flow ceases): } \\
\text { Rheophiles }\end{array}$} & Gammaridae (M) & 6 \\
\hline & Baetidae (Baetis ONLY) (E) & 7 \\
\hline & Leptophlebiidae (Paraleptophlebia ONLY) (E) & 6 \\
\hline & Perlodidae $(\mathrm{P})$ & 7 \\
\hline & $\begin{array}{l}\text { Nemouridae (Protonemura, Amphinemura \& } \\
\text { Nemurella) }(\mathrm{P})\end{array}$ & 7 \\
\hline & Taeniopterygidae (Taeniopteryx ONLY) (P) & 6 \\
\hline & Leuctridae $(\mathrm{P})$ & 7 \\
\hline & Aphelocheiridae $(\mathrm{H})$ & 7 \\
\hline & Scirtidae (Elodes ONLY) (C) & 6 \\
\hline & Brachycentridae $(\mathrm{T})$ & 6 \\
\hline & Lepidostomatidae $(\mathrm{T})$ & 7 \\
\hline & Glossosomatidae $(\mathrm{T})$ & 7 \\
\hline & Philopotamidae (Chimarra ONLY) (T) & 6 \\
\hline & Hydropsychidae $(T)$ & 5 \\
\hline & Leptoceridae $(\mathrm{T})$ & 5 \\
\hline & Polycentropodidae $(\mathrm{T})$ & 6 \\
\hline & Goeridae $(\mathrm{T})$ & 8 \\
\hline & Sericostomatidae $(T)$ & 7 \\
\hline & Simuliidae (D) & 6 \\
\hline & Pediciidae (D) & 7 \\
\hline & Empididae (D) & 6 \\
\hline & Stratiomyidae (D) & 7 \\
\hline & Muscidae (D) & 5 \\
\hline \multirow{2}{*}{$\begin{array}{l}\text { Early stages of pools shrinking: Moderately } \\
\text { tolerant lentic taxa (or extremely versatile lotic taxa) }\end{array}$} & Unionidae (B) & 6 \\
\hline & Coenagrionidae $(\mathrm{O})$ & 5 \\
\hline
\end{tabular}




\begin{tabular}{|c|c|c|}
\hline & Corduliidae (O) & 4 \\
\hline & Libellulidae (O) & 4 \\
\hline & Gomphidae (O) & 5 \\
\hline & Siphlonuridae $(\mathrm{E})$ & 5 \\
\hline & Ephemeridae (E) & 5 \\
\hline & Baetidae (Cloeon ONLY) (E) & 4 \\
\hline & Caenidae (E) & 5 \\
\hline & $\begin{array}{l}\text { Leptophlebiidae (Habrophlebia \& Leptophlebia } \\
\text { ONLY) (E) }\end{array}$ & 5 \\
\hline & Nemouridae (Nemoura ONLY) $(\mathrm{P})$ & 6 \\
\hline & Sialidae (Me) & 5 \\
\hline & Sisyridae $(\mathrm{N})$ & 6 \\
\hline & Elmidae (C) & 5 \\
\hline & Hydrochidae (C) & 5 \\
\hline & Helophoridae (C) & 3 \\
\hline & Ecnomidae $(\mathrm{T})$ & 4 \\
\hline & Molannidae $(T)$ & 5 \\
\hline & Tanypodinae (D) & 5 \\
\hline & Orthocladiinae (D) & 5 \\
\hline & Limoniidae (D) & 5 \\
\hline & Tipulidae (D) & 4 \\
\hline & Ptychopteridae (D) & 5 \\
\hline & Dolichopodidae (D) & 5 \\
\hline & Psychodidae (D) & 4 \\
\hline & Tabanidae (D) & 4 \\
\hline & Rhagionidae (D) & 5 \\
\hline & Athericidae $(\mathrm{D})$ & 5 \\
\hline & Planariidae (Tr) & 3 \\
\hline & Dugesiidae (Tr) & 3 \\
\hline & Lymnaeidae (G) & 2 \\
\hline & Physidae (G) & 3 \\
\hline & Sphaeriidae (B) & 2 \\
\hline & Asellidae (M) & 2 \\
\hline & Corixidae $(\mathrm{H})$ & 2 \\
\hline & Gerridae $(\mathrm{H})$ & 2 \\
\hline & Hydrometridae $(\mathrm{H})$ & 2 \\
\hline & Notonectidae $(\mathrm{H})$ & 1 \\
\hline Final stages of pools drying: Highly tolerant lentic & Naucoridae $(\mathrm{H})$ & 3 \\
\hline taxa & Veliidae $(\mathrm{H})$ & 2 \\
\hline & Mesoveliidae $(\mathrm{H})$ & 2 \\
\hline & Gyrinidae (ADULTS ONLY) (C) & 2 \\
\hline & Hydrophilidae (C) & 3 \\
\hline & Scirtidae (EXCLUDING Elodes) (C) & 3 \\
\hline & Dytiscidae (C) & $1^{*}$ \\
\hline & Ephydridae (D) & 2 \\
\hline & Chironomini (D) & 1 \\
\hline & Culicidae (D) & 1 \\
\hline & Syrphidae (D) & 1 \\
\hline & Ceratopogonidae $(\mathrm{D})$ & $1^{*}$ \\
\hline & Planorbidae (G) & 1 \\
\hline or able to survive in moist streambed & Dytiscidae (C) & $1^{*}$ \\
\hline & Ceratopogonidae $(\mathrm{D})$ & $1 *$ \\
\hline $\begin{array}{l}\text { Taxon group abbreviations are as follows: E, Ephemeroptera; } \\
\text { Hemiptera; C, Coleoptera; L, Lepidoptera, D, Diptera; M, Malacos } \\
\text { Tricladida }\end{array}$ & $\begin{array}{l}\text { Plecoptera; T, Trichoptera; G, Gastropoda; O, } \\
\text { aca; B, Bivalvia; Me, Megaloptera; N, Neuropter }\end{array}$ & \\
\hline
\end{tabular}


183 DEHLI is based on the calculation of an average of the component Drought Intolerance Scores in 184 Table 1, using the following equation:

Where $\mathrm{n}=$ the number of scoring taxa in the invertebrate sample.

DEHLI index values towards 10 imply little or no evidence of an ecological drought effect and values towards 1 imply significant effects associated with the advanced stages of a drought.

Some taxa are capable of existing at either end of the continuum, such as the stonefly family Nemouridae, some species of which thrive in lotic conditions but some taxa can, at least in the short term, survive in wet interstices where the surface water is virtually absent; or the caddis family Phryganeidae, which is closely associated with lotic marginal habitats but can also survive in lentic environments with negligible marginal habitat. The utility of these examples is in demonstrating the step-change associated with drought at an early stage, such as the loss of rheophilic (flowing) conditions (Nemouridae) or marginal habitat (Phryganeidae). At a later stage of drought development, the taxa may become concentrated in the remaining habitat patches which persist, though occurring under sub-optimal conditions. Therefore, these taxa have been given a DIS to reflect the changes occurring during the earliest stage of the drought / ramp disturbance. It is possible that DEHLI values could be inflated during drought extremes, but the current weightings will help highlight any loss of taxa during the early stages of drought (as thresholds of lateral and longitudinal connectivity are severed) and their recolonisation during the recovery phase.

To ensure reproducibility of the final metric, the index should ideally be derived from samples obtained using the standard protocols employed by the UK regulatory bodies (Environment Agency, Natural Resources Wales, Scottish Environment Protection Agency and Northern Ireland Environment Agency) as outlined in Murray-Bligh et al. (1997). This involves timed three-minute pro-rata multihabitat sampling with a Freshwater Biological Association pattern pond-net (square aperture of 0.5 $\mathrm{m}^{2}, 1-\mathrm{mm}$ net mesh) with an additional 1-minute hand search. This has been demonstrated to produce a good consistency and comparability of data and representation of the fauna present (Furse et al., 1981; Birk and Hering, 2006).

Although DEHLI has been designed to operate at family level, some adjustments would be required at the genus level in calculation of the index, as some families include genera with starkly differing habitat requirements (see, for example, Leptophlebiidae and Taeniopterygidae in Table 1). Therefore, it is recommended that data used to derive the metric should be resolved to species level wherever practical, both to ensure accurate calculation of the metric and to facilitate the derivation of complementary metrics used as part of routine monitoring or for specific pressures, such as the Loticinvertebrate Index for Flow Evaluation (LIFE - Extence et al., 1999), Proportion of Sediment-sensitive Invertebrates index (PSI - Extence et al., 2011), mixed level empirically-weighted PSI (E-PSI, Turley et al. (2016) and Community Conservation Index (CCl - Chadd and Extence, 2004). Furthermore, there is evidence which suggests that the highest possible level of taxonomic resolution produces metric outputs of maximum efficacy (e.g. Monk et al., 2012, Pickwell, 2012, Vilmi et al. 2015).

\section{$221 \quad 2.2$ Study sites}

DEHLI has been designed for wide application across a range of temporal scales and river types.

Below we illustrate its application using two case studies from England at different temporal resolutions and a modelling exercise demonstrating the response of DEHLI to a hypothetical multiyear drought, across a wider spatial scale. All of the case study sites and examples presented are located on calcareous geologies for reasons of data availability, but the index is applicable to other geological settings, in the UK and more widely. 
Apart from changes in water quantity, none of the sample sites used in provision of data were subject to any other significant stressors, such as anthropogenic water quality issues or substantial morphological modifications. This was to ensure that confounding factors did not adjust the target metric output, specifically, the impact of habitat loss mediated by reducing water availability. As outlined above, this does result in 'natural' changes in water quality in the final stages, but this concept has been integrated into derivation of the index.

\section{Figure 2: Location of the three study}

\section{5 sites.}

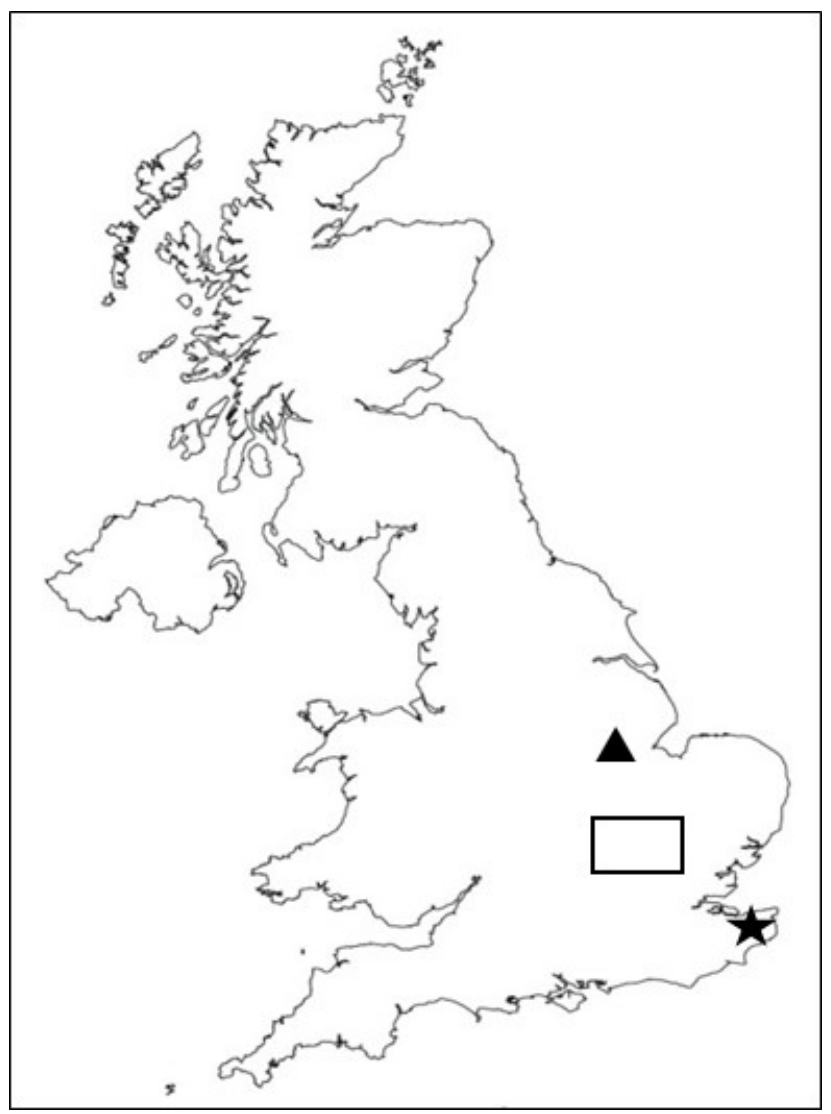

\section{2.2.1 River Tham (Glen Brook), Lincolnshire}

238 The River Tham (also known as Glen Brook) is a small calcareous stream draining a catchment of $23924.3 \mathrm{~km}^{2}$ in Lincolnshire, UK. It rises $1.1 \mathrm{~km}$ southeast of North Witham at $115 \mathrm{~m}$ aOD, and flows for $24011 \mathrm{~km}$ in a south-easterly direction before joining the West Glen at Little Bytham (Figure 2). The river 241 rises from a limestone aquifer, the nature of the rock making the bed prone to fracture. As a result, as flows naturally decline in summer, the presence of natural sinkholes leads to near-total cessation of surface flow (see Figure 2). This provided a useful opportunity to study the ecological effect of drying across four seasons. Invertebrate data were collected monthly over 14 months (November 2007 December 2008) from a site upstream of Park House Farm, 3.4km downstream of its source (SK 96547 20463). Samples were taken following the standard three-minute protocol, sampling habitats in proportion to their occurrence, with 1 minute additional hand searching (Murray-Bligh et al., 1997; ISO, 2012).

\subsubsection{Little Stour, Kent}

The Little Stour River is $11.5 \mathrm{~km}$ long, with a catchment area of approximately $213.3 \mathrm{~km}^{2}$ rising about $4 \mathrm{~km}$ east of Canterbury (Figure 1). Together with the Nailbourne River, an intermittent winterbourne 
stream, and the Wingham River, it forms a tributary of the Great Stour. Although the river rises from chalk, gravels and alluvium are found in the lower valley (Wood and Petts, 1999). Regular annual monitoring was undertaken between 1992 and 2001 to assess macroinvertebrate responses to low flow variability (see Wood and Petts, 1999; Wood et al., 2000 and Wood and Armitage, 2004 for more detail). Invertebrate samples were collected in early September using a non-standard methodology (two-minute kick sample with a $250-\mu \mathrm{m}$ mesh pond net). The primary site of interest was located adjacent to the village of Wickhambreaux and was dry in the 1992 and 1997 drought periods.

\subsubsection{Modelling the effect on Chiltern and Hertfordshire chalk streams}

Eight sites draining an area of Cretaceous Chalk which forms the Chiltern Hills and extends into Hertfordshire were used in the modelling exercise (Figure 3). The rivers form the upper tributaries of the Rivers Lee and Colne within the Thames Basin and include the Rivers Ash, Mimram (River Lee catchment) and Ver, Gade, and Misbourne (River Colne catchment). The sites were chosen to have relatively complete data records over the period 1988 to 2013, a total of 114 macroinvertebrate samples being available for analysis. Macroinvertebrate samples were collected according to the protocols as described for the River Tham above, with data from the northern hemisphere spring (March-May) and autumn (September-November) seasonal sampling periods being used in the analysis.

\section{Figure 3: Location of the study sites within the modelling analysis.}

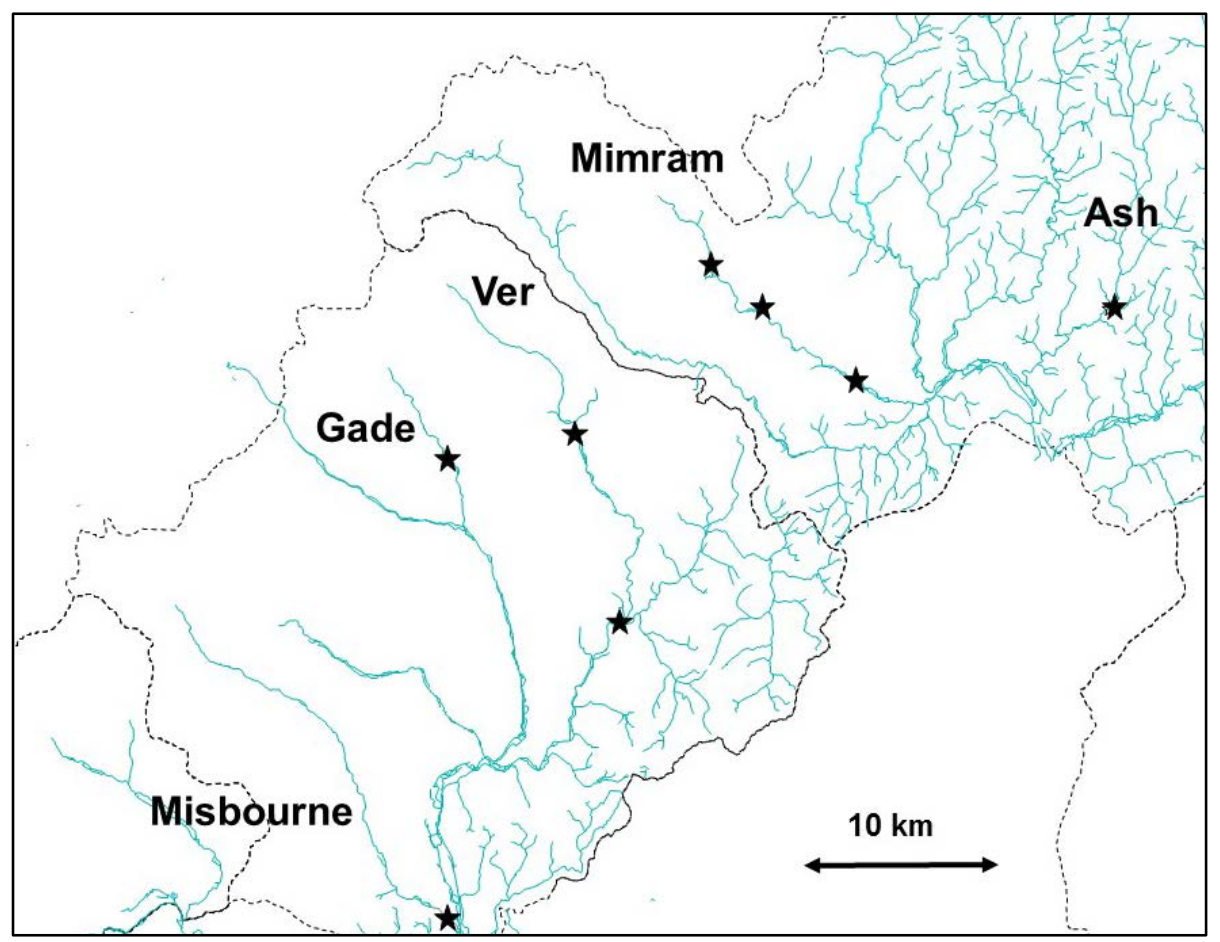

Each site was paired with an Environment Agency flow gauging station on the same river reach. In each case the flow regime at the gauge was assessed to ensure its representativeness of the flow history of the paired macroinvertebrate sampling site, with no major intervening flow discontinuities caused by either tributary inflows, abstractions or discharges. Daily mean flow time series from 1986 and 2014 were extracted from Environment Agency archives and divided into six monthly flowseasons for the summer (186 days) and winter (185 or 186 days for leap-years) periods. Hereafter, the six-month summer and winter periods (summer, winter) are referred to as flow-seasons to avoid confusion with the three-month macro-invertebrate sampling seasons (spring and autumn). For each flow record and each individual flow-season, a flow duration curve was derived and summarised into three easily calculated and widely utilised flow statistics: flow magnitude exceeded for $95 \%, 50 \%$ and 
$10 \%$ of the time (hereafter Q95, Q50, Q10), indexing the high, medium and low aspects of the flow series and resulting in a time series for each gauge and statistic on a six monthly time-step. Finally, to place the flows on a common scale, each series ( $7 x$ gauges, $2 x$ flow-seasons, $3 x$ statistics) was standardised by deriving z-scores for each site (Kreysig, 1979).

The procedure for matching the seasonal antecedent flow data to the seasonal macroinvertebrate sample indices broadly followed the methodology outlined in Dunbar et al. (2010a, 2010b). The seasonal (summer $=$ April to September, winter $=$ October to March) six monthly aggregate antecedent flow statistics describing both high and low flow events during those periods were derived, and then matched to the biotic scores on a sample by sample basis (sample-season autumn matched to flow-season summer, sample season spring match to flow-season winter). Furthermore, in order to investigate the response to antecedent drought, each sample was then also matched to lagged low flow (Q95) statistics for summer flow-seasons one (suffixed LS1 - lagged summer 1) and two (suffixed LS2 - lagged summer 2) calendar years prior to sampling.

In order to compare the properties of DEHLI and LIFE calculated from the macroinvertebrate data sampled in the spring and autumn sampling periods, four separate models were calibrated (DELHIspring, DELHI-autumn, LIFE-spring, LIFE-autumn). The modelling approach broadly followed that described in Dunbar et al (2010a, 2010b): essentially multilevel/mixed effects multiple linear regression of the selected macroinvertebrate index, using seasonal standardised flow statistics as explanatory variables. Two broad modifications were:

1. The models were simplified so that only a site random intercept term was fitted. No attempt was made to evaluate random slope terms for any explanatory variable, due to the relatively small number of sites, and the aim of the exercise being to describe the general pattern.

2. The models were extended to predict the selected macroinvertebrate index using the wider series of lagged flow terms described above - not only flows from the immediately antecedent flow-season but also from the summer flow-season one and two years prior to sampling. Furthermore, selected interaction terms were fitted: between terms representing both high and low flows in the immediate antecedent period, and between summer low flow terms in different years (Table 2).

Following Dunbar et al. (2010b), a linear year trend term was fitted to account for a general increase in scores over time not related to inter-annual changes in flow.

Multi-model inference (Burnham and Anderson, 2002, Anderson 2008; Grueber et al. 2011) was used to tabulate a model set with a realistic degree of complexity while avoiding over-fitting arising from the relatively large number of potential predictors (themselves inter-correlated) but relatively small number of sites and samples. The use of model ranking and multi-model inference ensured the models were robust to effects of correlations between explanatory variables which would otherwise act to inflate the standard errors of parameters when applying a simple stepwise approach to model simplification.

318 Models were ranked using corrected Akaike Information Criterion (AICC) values (Burnham and Anderson, 2002). All models with an AICc $\Delta_{i} 4$ of the top model were tabulated.

\section{Table 2: Summary of explanatory variables.}

\begin{tabular}{|l|}
\hline Main effects \\
\hline Q95, Q50, Q10 flows in flow-season immediately prior to sample being \\
taken (winter flows-spring samples, summer flows-autumn samples) \\
(Q95z, Q50z, Q10z) \\
\hline Q95 flows in summer before year of sample (Q95zLS1) \\
\hline Q95 flows in summers before year of sample (Q95zLS2) \\
\hline Calendar year of sample (1998 taken as base year) \\
\hline
\end{tabular}




\begin{tabular}{|l|}
\hline Interaction effects \\
\hline Q95z: Q10z \\
\hline Q95z: Q95zLS1 \\
\hline Q95zLS1: Q95zLS2 \\
\hline Q95z: Q95zLS2 \\
\hline
\end{tabular}

322 Having produced four multi-model sets, the resulting weighted multi-models were used to predict LIFE 323 and DEHLI response in the spring and autumn season to a developing synthetic multi-year drought, 324 with flows at average levels in the first year, progressively declining over the next four years, and then 325 a relatively rapid recovery in flows beginning in the next following winter, and proceeding for a further 326 two years. Although the year trend was highly significant and positive, for this exercise it was not used 327 in the predictions.

328 3. Results

\subsection{River Tham (Glen Brook), Park House Farm, Lincolnshire}

330 Figure 4: DEHLI and LIFE response, plus mean surface water flows at 331 downstream gauge-point (Castle Bytham $3.9 \mathrm{~km}$ downstream of sample point), 332 with monthly sampling (November 2007 to December 2008), matched with 333 fixed-point photographic record (River Tham/Glen Brook). 

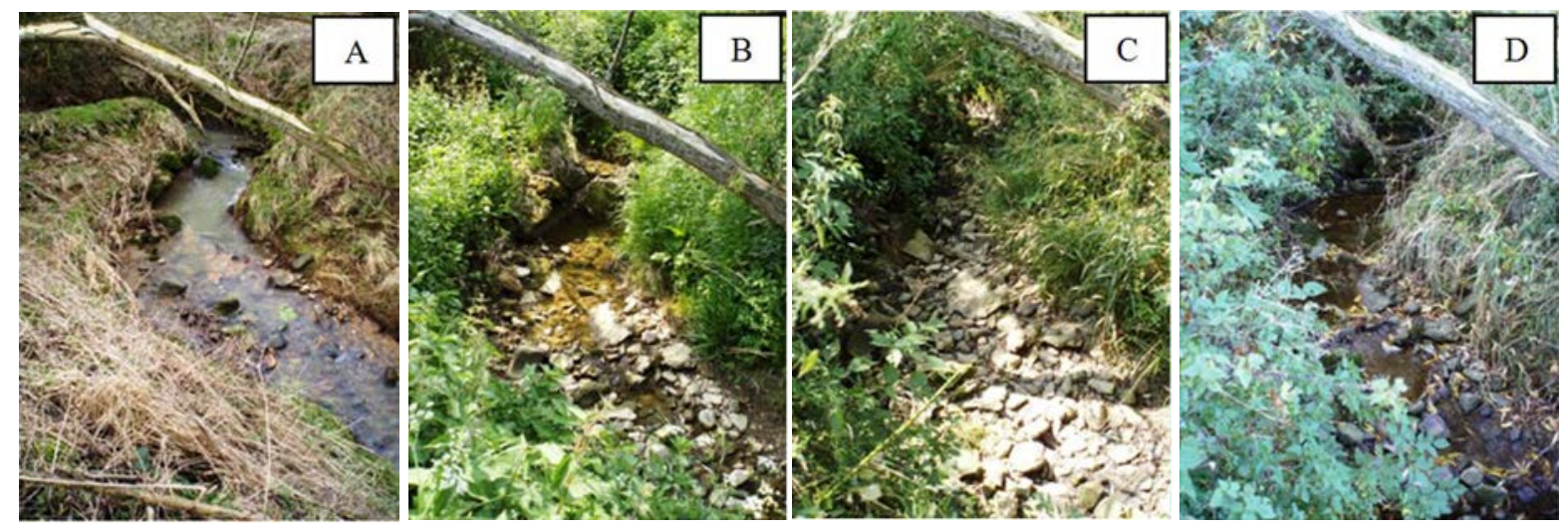

Flow $\rightarrow$ DEHLI - LIFE (F)
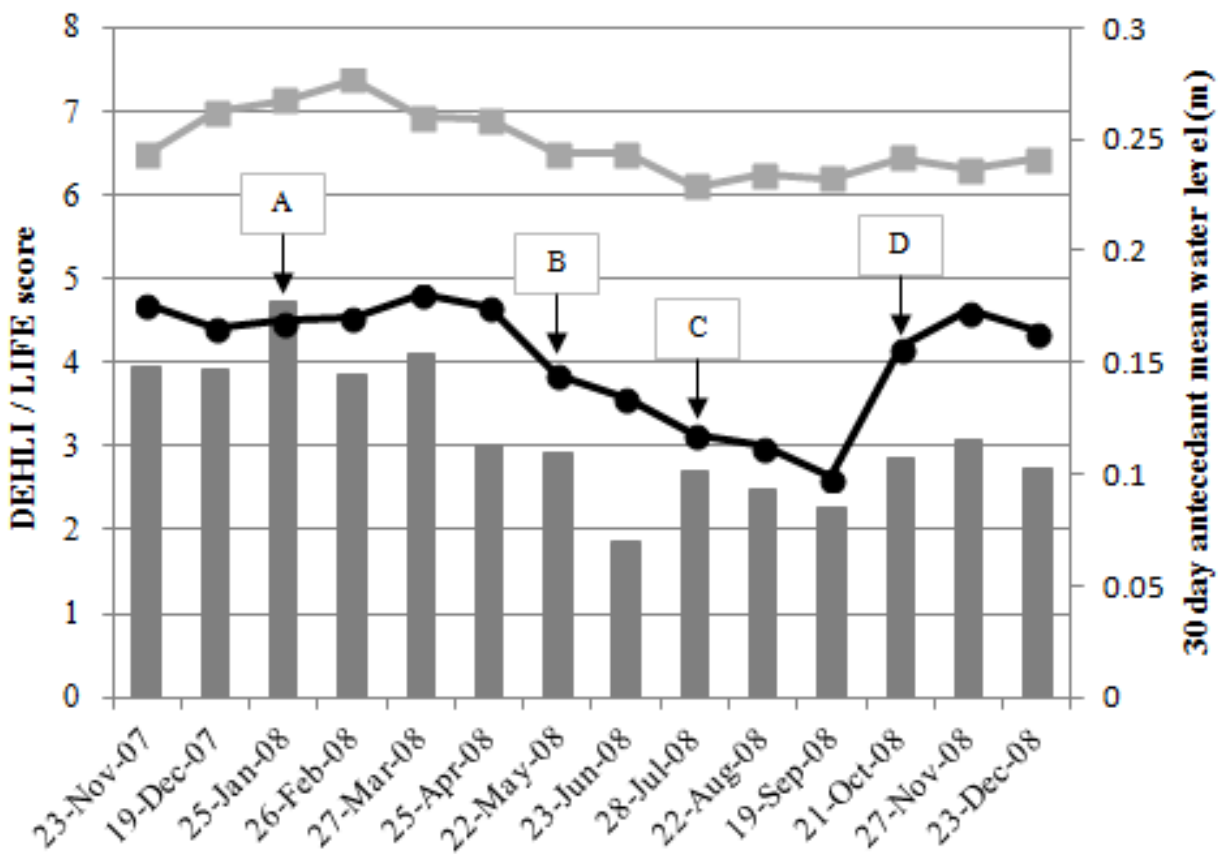

Table 3: Drought Intolerance Score (DIS) taxon list for time points A to D (R.

336 Tham) - see Figure 4.

\begin{tabular}{|l|l|l|l|}
\hline \multicolumn{4}{|c|}{ DIS taxa presence } \\
\hline 25-Jan-2008 (Photo A) & 22-May-2008 (Photo B) & 28-July-2008 (Photo C) & 21-Oct-2008 (Photo D) \\
\hline Baetis & Baetis & Dixidae & Pediciidae \\
\hline Pediciidae & Pediciidae & Gammaridae & Gammaridae \\
\hline Gammaridae & Gammaridae & Asellidae & Caenidae \\
\hline Caenidae & Caenidae & Vellidae & Elmidae \\
\hline Elodes & Elodes & Dytiscidae & Orthocladiinae \\
\hline Hydropsychidae & Hydropsychiidae & Gyrinidae & Elodes \\
\hline Limoniidae & Orthocladiinae & & Tipulidae \\
\hline Simuliidae & Helophoridae & & Psychodidae \\
\hline Orthocladinae & Hydrophilidae & & Lymnaeidae \\
\hline Helophoridae & Tipulidae & & Dytsicidae \\
\hline Tipulidae & Asellidae & Ceratopogonidae \\
\hline $\begin{array}{l}\text { Veliidae } \\
\text { Chironomini } \\
\text { Culicidae }\end{array}$ & Veliidae & \\
\hline & Dytiscidae & & \\
\hline
\end{tabular}


Key to DIS scores: white $=7$ or 8 , light grey $=5$ or 6, dark grey $=3$ or 4 and black $=1$ or 2

339 The results indicate that DEHLI scores responded to drought and its development in a more sensitive

340 manner than the LIFE index (Figure 4 and Table 3). From May 2008 and July 2008 there was a marked reduction in surface water flow to the point where much of the river bed was dry and exposed (Figure. 4B and 4C). LIFE scores, however, did not appear to respond to this, with scores remaining relatively stable until October 2008. In contrast, DEHLI tracked the severity of low flow conditions, with scores declining between May and July, through to September 2008, before some recovery in October, when significant surface water flows began to return (Figure 4D). During the early phases of drought development, from February 2008 (Figure 4A) to May 2008 (Figure 4B), the LIFE index responded more readily than DEHLI to the gradual reduction in flow velocities. LIFE scores over this period displayed a steady decline from 7.38 to 6.5 whereas DEHLI showed a limited response until May when there was a marked drop in score from 4.67 to 3.87 , likely to be the response to the crossing of a connectivity threshold, early year spate flows transforming into a slow flowing and shallow trickle during the initial stages of loss of longitudinal connectivity

The observed reduction in surface water availability and the associated progressive loss of habitat from January to July was reflected in the gradual loss of many mid-high scoring DIS taxa (Table 3). From January to May, when water levels began to decline and flow velocities were reduced, rheophilic taxa (e.g. Simuliidae and Limoniidae) disappeared and there was a concomitant appearance of lentic taxa (e.g. Asellidae and Dytiscidae). The further loss of rheophilic taxa continued through to July when there was a complete cessation of surface water flows and only small disconnected pools remained. At this point the invertebrate community became dominated by highly tolerant lentic taxa. When surface flows returned in October the rheophilic taxa returned quickly (e.g. Pediciidae and Elodes). 
Figure 5: Annual DEHLI \& LIFE response versus gauged discharge (Little $\rightarrow$ DEHLI $\rightarrow$ LIFE (F) Discharge

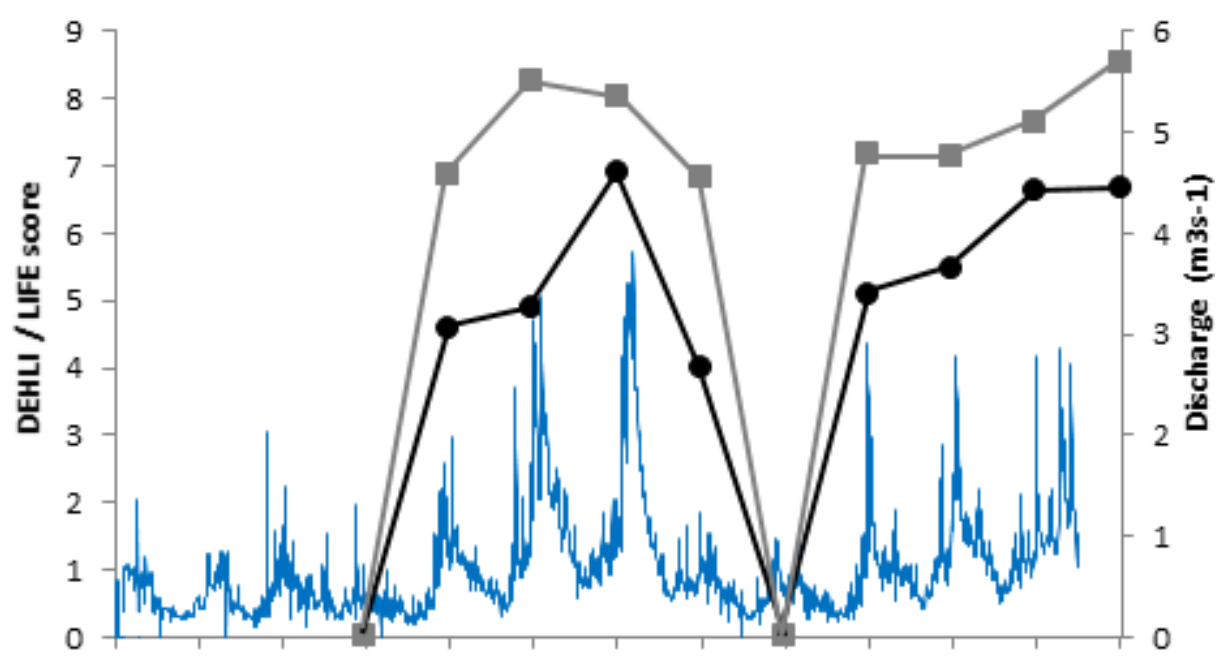

364 Stour).

Figure 6: Annual community composition (DIS taxa), Little Stour.

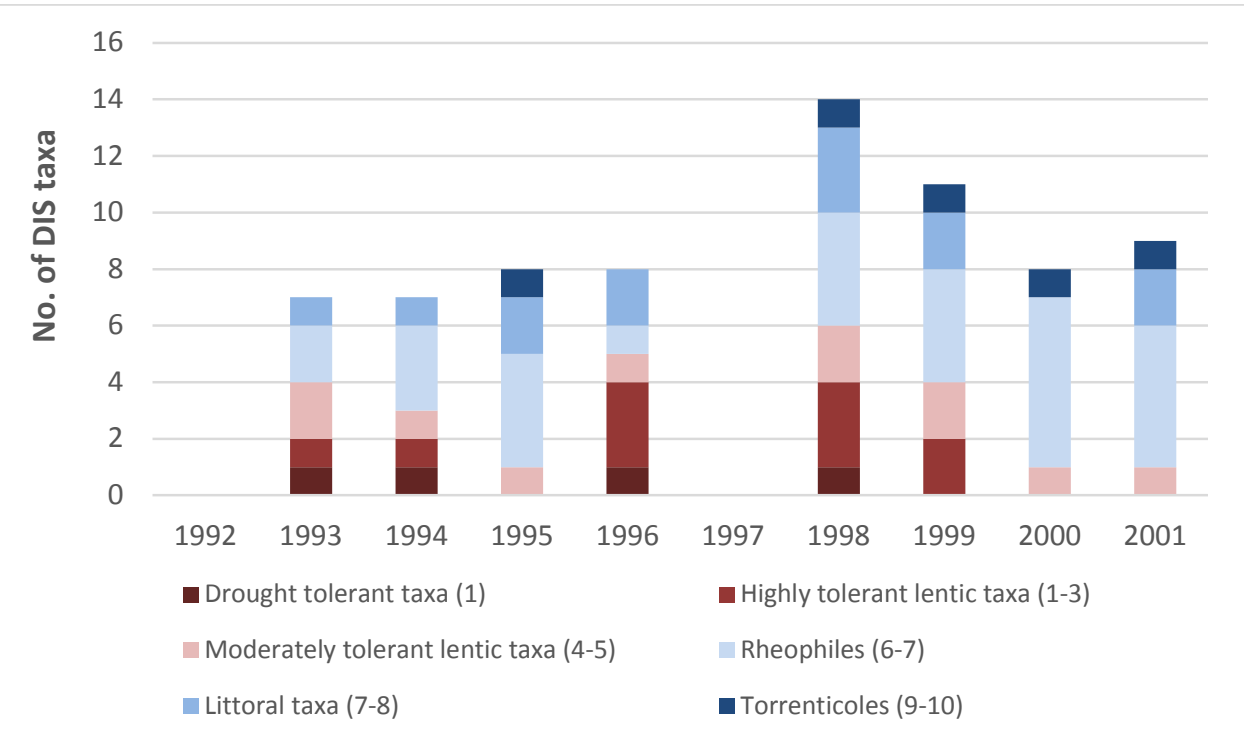

Annual DEHLI and LIFE (family) scores for the Little Stour from 1992 to 2001, together with river discharge are shown in Figure 5. The river channel was dry during the 1992 and 1997 sampling periods. Between the summers of 1991 until the end of 1992, terrestrial vegetation colonised the channel bed, with most of it being subsequently removed with the resumption of flows in 1993. There was a progressive increase in flows between 1993 and 1995, LIFE scores quickly peaked in 1994 at 8.25 before a gradual decline in scores with the 1996-97 drought (Figure 5). In contrast, from 1993 DEHLI rose consecutively for the next two years mirroring the gradual recovery of flows from drought effects, peaking in 1995. In 1996 both LIFE and DEHLI indicate a reduction in response to a second supra-seasonal drought, with DEHLI displaying a more marked deterioration with a score that fell below that of the recovery phase in 1993 , whereas LIFE declined to levels comparable to 1993. In 
377 1998, following the 1997 drought period, both metrics show similar levels of recovery to that recorded 378 following the 1991-1992 drought with scores comparable to 1993 values.

379 The resumption of surface water flows in 1993 saw the return of an invertebrate community with a 380 notable proportion of lentic taxa and a relatively low number of rheophilic taxa (Figure 6). This changed following the recovery of flow in 1994 and 1995, when faunal composition was dominated by rheophilic taxa (e.g. Rhyacophilidae, Glossosomatidae and Simuliidae). With the onset of the 1996 drought, there was a return to the dominance of lentic taxa and a major reduction of rheophiles associated with the loss of longitudinal connectivity on the river. With the return of surface water flows in 1998, there was a rapid recovery and peak in taxon richness (DIS taxa $=14$ ), which saw a strong mixture of both lentic and lotic taxa. Following the recovery period, 1999-2001, the number of low scoring DIS taxa declined, a result of the lentic taxa declining over the next three years from six to one, with the rheophilic taxa once again dominating the community.

\subsection{Chilterns streams: modelled drought response}

390 In all four cases (spring and autumn DEHLI and spring LIFE, autumn LIFE), ranking of model sets indicated the importance of more than one single model in describing the response of the indices to antecedent flow. DEHLI produced more candidate models than LIFE, and spring produced more candidate models than autumn (Table 4). Table 4 illustrates the numbers of models selected in a candidate set within an AICC of 4 for the top model, along with the relative importance of each explanatory variable. Relative importance illustrates the weighted proportion of candidate models with the variable present, hence 1.00 indicates that the variable was present in every candidate model. Residual vs fitted values plots were examined for each maximal model and indicated that model assumptions were valid. Generally the flow terms closest in time to the sampling date were most commonly selected, indicating the relatively greater strength and precision of response of the macroinvertebrate community to antecedent flows immediately prior to the ecological sample collection. The exception to this was for spring LIFE, where (flow-season winter) Q10z rarely appeared in the model set. Summer lagged low flows one and two years prior to sampling also appeared frequently. Overall this indicates the multi-faceted nature of the ecological response to flow, and confirms that at a broad level, both DEHLI and LIFE respond to inter-annual drought, not simply seasonal low flow. The most commonly occurring interaction effect was Q10z:Q95z, particularly for both autumn DEHLI and LIFE. The presence and direction of this interaction indicated that when antecedent summer high (Q10z) and low (Q95z) flows are lower than average, this is associated with lower index scores. Conversely, when both Q10z and Q95z are high, index scores are slightly lowered, although this may be a statistical artefact arising from the linear nature of the interaction effect. Given the groundwater influence in the studied catchments, summer Q10z indicates the influence of early summer high flows, whereas Q95z indicates the influence of late summer flows. 
413 Table 4. Relative importance for each explanatory variable in each of four 414 separate multi-model sets (within $\Delta$ AICc $=4$ of top model), and number of 415 models in each candidate model set.

\begin{tabular}{|l|c|c|c|c|}
\hline Variable & $\begin{array}{c}\text { DEHLI } \\
\text { spring }\end{array}$ & $\begin{array}{c}\text { DEHLI } \\
\text { autumn }\end{array}$ & $\begin{array}{c}\text { LIFE (F) } \\
\text { spring }\end{array}$ & $\begin{array}{c}\text { LIFE (F) } \\
\text { autumn }\end{array}$ \\
\hline Year & 1.00 & 1.00 & 1.00 & 1.00 \\
\hline Q95z & 0.69 & 1.00 & 0.83 & 1.00 \\
\hline Q10z & 0.57 & 1.00 & 0.17 & 1.00 \\
\hline Q10z:Q95z & 0.17 & 1.00 & 0.05 & 1.00 \\
\hline Q95zLS2 & 0.73 & 0.83 & 0.30 & 0.78 \\
\hline Q95zLS1 & 1.00 & 0.35 & 0.94 & 0.46 \\
\hline Q95z:Q95zLS2 & 0.19 & 0.23 & 0.12 & 0.72 \\
\hline Q95z:Q95zLS1 & 0.21 & 0.12 & 0.77 & 0.31 \\
\hline Q95zLS1:Q95zLS2 & 0.56 & & 0.05 & 0.06 \\
\hline $\begin{array}{l}\text { Number of models } \\
\text { in candidate set }\end{array}$ & 22 & 7 & 9 & 6 \\
\hline
\end{tabular}

417 Considering the predicted macroinvertebrate scores to the synthetic supra-seasonal drought (Figure 418 7), for the autumn community, DEHLI displayed a linear decline from "normal" conditions (defined as 419 a value of 0 for each standardised flow statistic) into increasingly severe drought. The reduction in 420 DEHLI was less marked in years 3 to 4 of the drought. In contrast, LIFE showed a slower initial 421 decline up to year 2, but it declined more rapidly in year 3, and while the decline became less steep in 422 year 4 , the rate was greater than for DEHLI. In terms of recovery, both indices recovered quickly 423 during the first year after the drought, with DEHLI recovering slightly more quickly. In the second year 424 of recovery, both DEHLI and LIFE recovered to levels above normal conditions. 

hypothetical multi-year drought.
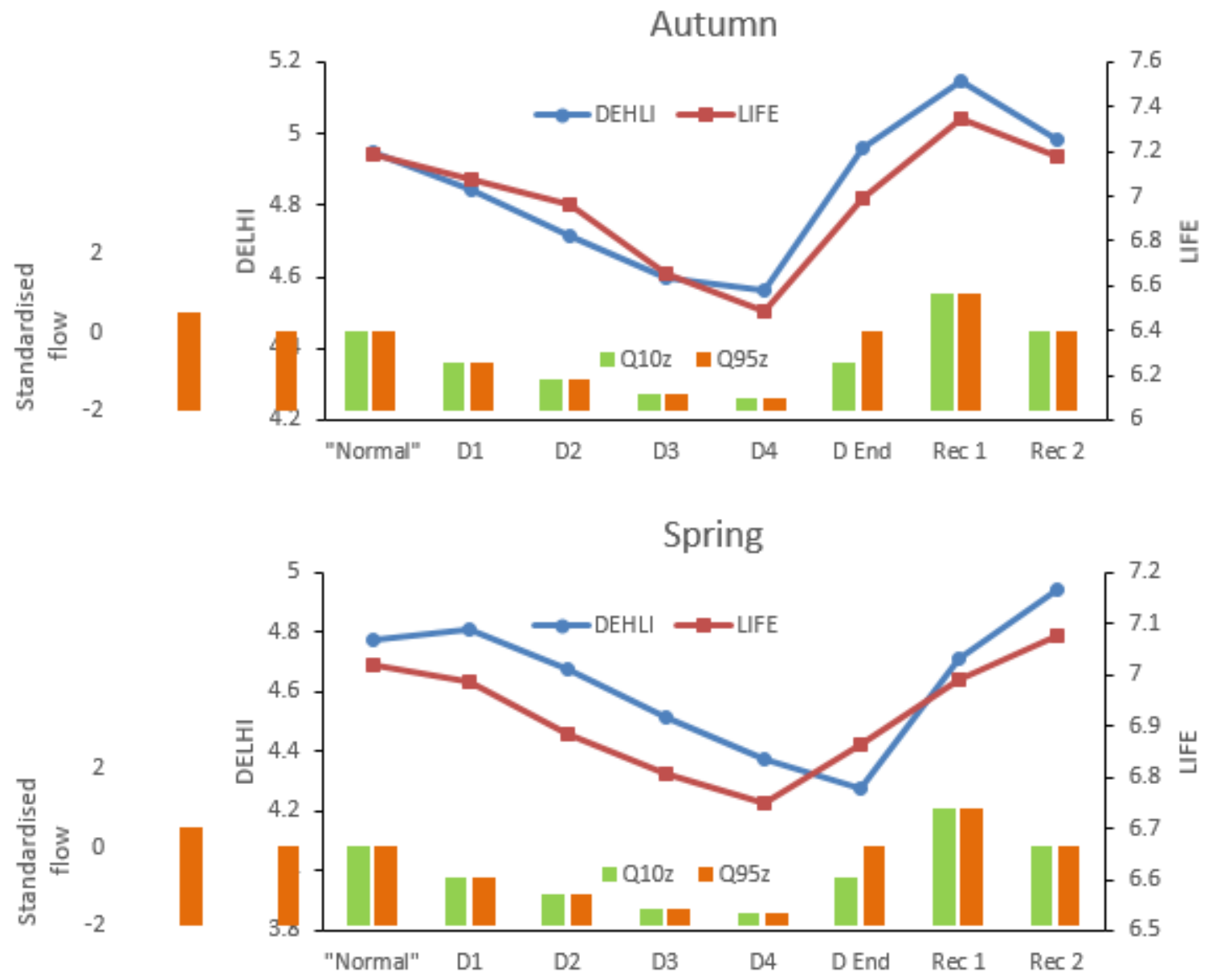

428 The Response of DEHLI and LIFE in spring differed from that of autumn. In autumn, the indices followed different trajectories during the developing drought conditions, whereas in spring, the indices showed a similar, relatively linear decline. Compared with the autumn community, however, the DEHLI scores for the spring community showed a notable lag in response as the synthetic drought developed, and continued to decline after the end of the drought. Once DEHLI began to recover, however, this occurred relatively rapidly, and again both indices recovered to levels above those at the beginning of the period

\section{Discussion}

The principle which underpins DEHLI is that the effect of drought on aquatic invertebrates follows a ramp disturbance and that this gradual change, punctuated by abrupt losses of habitat and concomitant loss of taxa, is a valuable model to help guide the management of freshwater ecosystems and the resources they support (Boulton, 2003; Boulton and Lake, 2008). It is widely documented that aquatic communities recover, even after the loss of surface water due to drought. Furthermore, it should be possible to re-establish ecological resilience through rehabilitation of degraded habitats (Boulton et al., 2010; Leigh et al., 2015). Studies over recent years have greatly improved our understanding of how rivers recover from drying events and the response of individual taxa (Stubbington et al., 2016; Datry et al., 2014, Leigh et al., 2016). Use of refugia and the degree of connectivity are important for survival in extreme drought (Reich and Lake 2014). Connectivity with 
446 the hyporheic zone is therefore of great importance (Boulton et al., 2010), as is the ability for life 447 stages of many taxa to persist within the "seedbank" (Stubbington and Datry 2013).

\section{$448 \quad 4.1$ An empirical approach to drought effects on ecology}

449 This raises questions regarding the need for an empirical metric. A drying river can be clearly 450 illustrated using a photograph. However, this is not necessarily the point at which a drought is exerting 451 an ecological effect. The response observed using DEHLI in the River Tham case study demonstrates rapid changes as the site began to contract into pools. The first important phase to be indicated as the drought effect deepened was when the reduction in flow resulted in an ecological step-change, indicated by the reduction in DEHLI scores from May through to September. These scores provide an 'impacted state' against which to measure subsequent recovery. The second important re-wetting and recovery phase during the drought was clearly shown in the results by the rise in DEHLI scores from September to November (Time-point D in Figure 4). DEHLI provides evidence of both the ramp effect of reduced flow and the recovery to pre-drought conditions with the resumption of flow (Point $A$ in Figure 4); in marked contrast to the relative stability recorded by LIFE scores over the same period. This provides firm evidence that instream habitats were sufficiently complex and the concomitant adaptation of the invertebrate community resistant to the effects of drying that they were able to recover / re-colonise following the severe low flows. The empirical measures from January through to April (prior to the drought onset) effectively provide the baseline condition for the site to achieve once flows return. It is, of course, possible that the baseline condition at the Tham site is already permanently degraded and the river has developed over a number of years to support a relatively impoverished fauna. Thus, the ecological condition recovered from a state degraded by drought to a lower baseline, so that the process was more rapid, but intervention to restore the habitat to a better, more natural 'baseline state' is still necessary. This can easily be tested using predictive modelling and empirical measures such as DEHLI are ideal for such a purpose. This strategy has proved successful elsewhere in approaches to managing flows (e.g. Dunbar et al. 2010a, 2010b) and the incorporation of DEHLI scores to help understand, quantify and ameliorate the effects of drought could be a useful additional tool to draw upon. In essence, the ability DEHLI provides to give empirical measures to nebulous processes such as drought recovery is of great utility in environmental management. For example, DELHI can be used to compare a variety of locations along a river during drought, potentially revealing 'sentinel' locations where managers might most usefully site their sampling stations to detect the early stages of water shortages (due to natural or anthropogenic drought).

\subsection{Informing river management processes and decision-making}

In river reaches where resilience is low or where they are subject to high magnitude supra-seasonal droughts (as illustrated by the Little Stour River case study), the effect of a drought indicated by the DEHLI index may be extended over more than one year. Thus, the method may provide evidence to identify sites where there is a need to increase habitat complexity and ecological resilience. At an operational level, this may be achieved by managing abstraction, by undertaking morphological restoration measures, or both. Consequently, by applying DEHLI and the principles which underlie it, we can both monitor the effects of drought associated with short-long term weather patterns and prioritise where intervention may be required to increase resilience to the impacts of climate change and anthropogenic activities. For the UK, there is, to date, little evidence of changes to drought or low flow frequencies, although some studies indicate increases in the magnitude and frequency of short droughts (<18 months) in the future (Watts and Anderson 2013; Watts et al., 2015). Addressing morphological degradation is a widely accepted approach in adapting to climate change to help protect our rivers from extreme events including drought (Henriques et al. 2015 and Orr et al. 2015), increase ecological resilience (Dunbar et al. 2010a, 2010b and Dokulil 2016) and protect ecosystem services (Zalewski, 2014). 


\subsection{Tracking long-term drought effects on ecology}

The Little Stour case study clearly illustrates both the immediate effect of drought and subsequent recovery associated with two high magnitude supra-seasonal droughts. There was a marked upward shift in taxon richness in the Little Stour following the return of surface water in 1998 (Figure 6), with a mixture of lentic and lotic taxa occurring. This is likely to be the consequence of a transitional recovery period, following the end of the drought which is often characterised by a high flow event (Parry et al., 2016) so that both types of taxa were able to coexist until higher flows occurred during the subsequent winter. Following the recovery period, a number of lentic taxa disappeared and rheophilic taxa once again dominated the community. The greater taxon richness observed on the Little Stour in 1998 after drought compared with 1993 (Figure 6) may be due to the relative severity of the preceding droughts. The drought prior to 1998 was shorter in length: two years (1996-97) compared with four years (1989-1992) prior to 1993. It is probable that the increased severity of the 1989-1992 drought exerted a greater effect (drying the riverbed at the study site for more than 12 months) and as a result it took longer for the recovery of the invertebrate community to occur, with full recovery, as shown by DEHLI, not occurring until 1995. This change in community taxonomic composition may be expected, given that drought acts as an important natural disturbance, modifying macroinvertebrate communities and their associated food webs (Atkinson et al., 2014; Lu et al., 2016). In contrast, James and Suren (2009), working in lowland New Zealand, found that the effects of increased duration and magnitude of flow reduction on invertebrate communities was restricted to changes in the abundances of relatively few taxa. Previous workers have found that the magnitude of impact varies with the duration of the drought and streambed drying events (e.g. Wood and Petts 1999, Wood et al. 2000, Stubbington et al., 2009 and Datry, 2012). Fundamental to the impact of drying is the severity of the event and the effect of flow permanence, with clear differences between sites that are usually perennial and naturally intermittent river reaches (Extence, 1981, Boulton, 2003, Lake, 2003, Smith et al., 2003, Boulton and Lake 2008).

\subsection{Incorporation in multi-metric approaches}

520 In the current study, the combined use of LIFE and DEHLI was useful for observing the changes associated with drought and in helping to interpret their probable causes, as the strength of both indices lies in an inherent basis with an explicit mechanism. Following the return of surface water on the Little Stour, the LIFE index rapidly returned to pre-drought conditions (within 1 year - following both 1989-1992 and 1996-1997 events), reflecting the resilience of the rheophilic/torrenticole community and their effect on the derivation of the LIFE score. In marked contrast, the DEHLI index indicated ongoing effects up to 1999, two years after the return of flows, with drought-tolerant and highly tolerant lentic taxa still forming a major component of the community. The ecological mechanisms which underpin the indices, relating to habitat loss for DEHLI and flow velocity response for LIFE, explain the differences recorded. Drying can result in the local extinction of fauna associated with particular habitat types (e.g., when riffles become exposed as water level declines), so recovery may require recolonisation, perhaps from sources beyond the local environment. Recolonisation may be further constrained by seasonal patterns of invertebrate reproduction and/or differences in dryingresistant life stages. The less responsive nature of LIFE during drought reflects its sensitivity to reducing water velocities. Examination of LIFE scores from both case studies clearly indicates that small populations of rheophilic and torrenticole taxa persisted, especially in environments with habitat which is less degraded and more resilient to reducing flows. Thus, the capacity remained for rapid recolonisation and recovery once velocities rose. These differences reflect the scores assigned to taxa, for example, the dragonfly family Aeshnidae were allocated a high DIS of 7 (Table 1), reflecting loss of lateral connectivity. In the LIFE index, the same family is assigned to Flow Group IV, indicating a preference for still water environments or marginal dead waters in rivers. As a result we would advocate the application of multiple metrics wherever possible. The use of multiple metrics is a welldocumented approach when attempting to disentangle the relative responses to multiple stressors within aquatic environments (e.g. Extence et al. (in press)). For example, Clews and Ormerod (2008) 
544 in their study of the Welsh River Wye, concluded that simple pressure-specific indices have bio545 diagnostic capability and advocated the further development and testing of the combined use of 546 pressure-specific metrics in other locations. It is widely acknowledged as best practice not to use 547 biotic indices in isolation, but to test all potential stressors against the same dataset. The UK 548 regulatory bodies routinely undertake this approach, plotting modelled index scores as a ratio against 549 observed scores, to simultaneously demonstrate organic pollution stress, fine sediment deposition 550 and flow stress. These outputs are further modified by consideration of physical modification and 551 measures of trophic state. It is suggested that, used in combination and informed by the use of other 552 pressure-sensitive indices, the LIFE and DEHLI indices will improve our understanding of how aquatic 553 invertebrate communities respond to drought.

554 The modelling of integrated data from the Chilterns streams was undertaken to compare the response of DEHLI and LIFE to changes in flow associated with drought over a wider spatial and temporal scale and to further understand the relative properties of the two complementary approaches. The results showed differential response by season. The delay in response of DEHLI to returning flows in spring is likely to be due to a season-driven lag in recolonisation and perhaps to the persistence of drought tolerant fauna (also reflected in the empirical case studies). The loss of fauna as the marginal habitats dried during drought would be followed by a subsequent reconnection in autumn through to the following spring. Whilst the habitat was subsequently reconnected, recolonisation may have lagged behind because of a delay relating to breeding season in late spring and early summer, as well as the need for recovery of resources, such as food supplies, to sustain populations. In comparison, LIFE response to rising flow velocities and establishment of mid-channel rheophiles in the early part of the year would be more rapid, as recolonisation would be derived from the maintenance of populations in refugia. Autumn response, by contrast, shows different trajectories between the two indices. DEHLI shows a steady decline associated with the impacts of the ramp disturbance, whereas LIFE may remain elevated as taxa move into high-velocity refugia, masking the early impacts of drought. The results of both the modelling and field investigations illustrate how access to refugia, including flowing water refugia, (Reich and Lake 2014) such as isolated riffles and the hyporheic zone (Stubbington and Datry 2013, Stubbington et al. 2015 and Verdonschot et al. 2015) is critical to the drought recovery process.

The results of the modelling exercise indicate interaction effects between antecedent high (Q10 - high flow exceeded only $10 \%$ of the time) and low flows (Q95 - low flows exceeded $95 \%$ of the time), demonstrating the potentially complex ways in which macro-invertebrate communities may be influenced by antecedent flows. Whilst the choice of flow statistics in the modelling exercise was guided by previous work, there are likely to be other ways of summarising flow data in an ecologically useful way, perhaps guided by the various questions to which DEHLI might be applied. Groundwater recharge during the winter is regarded as the dominant control on the flow regimes in the rivers studied in the Chilterns. Hence, for the summer period (April to September), the highest flows occur in the early part (April-May), and the low flows typically occur later (August-September). This illustrates the importance of April-May flows in controlling the autumn macro-invertebrate community (Wood et al. 2000; Wood and Armitage 2004) and is reflected in the response of the two indices. It is important to recognise that DEHLI has been designed to reflect progressive step-changes to habitat as droughts proceed, whereas LIFE responds to changes in flow velocities and as a result, DEHLI is more sensitive to change as lotic ecosystems enter into and exit from severe drought. The modelling exercise reinforces the potential utility of the multi-metric approach advocated by Clews and Ormerod (2008).

\section{$589 \quad 4.5$ Conclusions and future work}

590 DEHLI presents a valuable tool to help gauge the effects of drought (historic and in real time), guide empirical measure for decision-making in environmental management is of paramount importance, as 
593 it facilitates the use of complex ecological data for strategic decisions, potentially made by non594 specialists. Its use in highlighting habitat loss through ramp disturbance adds to existing tools 595 available to guide riverine management decisions associated with habitat restoration programmes, 596 enhancement of ecosystem resilience and regulatory licencing strategies. In this study, we have 597 utilised the data widely available from the UK regulatory bodies following standard approaches, such 598 as those outlined by Murray-Bligh et al. (1997) and ISO (2012). While it is preferable to utilise a 599 sampling method that covers all habitats present within a site to understand the full impacts 600 associated with drought and associated habitat changes, it is possible to employ other methods of 601 sampling, (e.g. fully quantitative methods such as the Surber sampler, see Chadd, 2010), so long as 602 the methods are used consistently in comparison of metric outputs. Both semi- and full-quantitative 603 methods used in standard protocols derive abundance data for taxonomic categories. It is recognised 604 that DEHLI, unlike other metrics such as LIFE, does not have an abundance weighting in the manner 605 in which it is derived. Future work could look to incorporate these data into the final metric, so as to 606 provide a potentially more accurate measure of drought effects on instream ecology. Consideration 607 should also be given to sampling the full habitat composition at a site in a drying river, including bed 608 sediments. Alternative techniques being developed in the monitoring of temporary rivers and 609 ephemeral streams, such as the rewetting of river bed-sediment (see Stubbington et al. 2016) and 610 sampling of macroinvertebrates of exposed riverine sediments and riparian zones, will help in our 611 understanding of how rivers are affected by and respond to drought. Taking this approach might have 612 amplified the DEHLI response in the Tham and Little Stour case studies, by incorporating fauna fully 613 adapted to states close to full drying and moderating the influence of rheophilic taxa surviving in 614 pools. Further research into the use of broader suites of riparian taxa should examine the efficacy of 615 such approaches and determine the value of their adoption by regulatory bodies.

Furthermore, it is acknowledged that the river typologies used in this paper are all on calcareous geologies in lowland areas of the south and east of England and consequently largely fed by groundwater. Future work should look to test the index in surface-input impermeable geologies and/or in upland areas of Britain as well as expanding its use into continental Europe in both upland and lowland topologies. It is anticipated that ecological changes will be much more abrupt in surface-water dominated, particularly upland, catchments, as habitat loss and re-wetting are likely to be over a shorter time scale. Expanding the geographical and topological scope of the index (including potential application in different continents, with some taxonomic adaptation) may further encourage its wider use in regulation and research efforts worldwide.

\section{Acknowledgements}

The authors would like to thank all of the Environment Agency staff involved in collecting and analysing data from the Tham site and Chilterns sites. We are also grateful for the continuing help and support of our colleagues in commenting on drafts and ideas and assisting with data analysis. For the EA, this includes Darren Finnie, Emma Holden, Holly Longstaff, Alex Pickwell, Sian Ratcliffe, Jake Reeds and Nina Birkby. We also thank Andrew Boulton for helpful comments on the draft and Andrew and Sam Lake for proposing and sharing the original ideas which inspired this paper. We are grateful to the Environment Agency of England for facilitating this research and very grateful to two anonymous reviewers for helpful and constructive comments which greatly enhanced the paper. The views expressed within this paper are those of the authors and do not necessarily represent the views of their organisations.

\section{References}

Acreman, MC, and Ferguson, JD. 2010. Environmental flows and the European water framework directive. Freshwater Biology 55: 32-48. doi: 10.1111/j.1365-2427.2009.02181.x 
643 Anderson, DR. 2008. Model based inference in the life sciences: a primer on evidence. Springer 644 Verlag, New York.

645 Armanini, DG, Monk, WA, Tenenbaum, DE, Peters, DL and Baird, DJ. (2012). Influence of runoff

646 regime type on a macroinvertebrate-based flow index in rivers of British Columbia (Canada).

647 Ecohydrol., 5: 414-423. doi:10.1002/eco.234

648 Atkinson, CL, Julian, JP and Vaughn, CC. 2014. Species and function lost: Role of drought in

649 structuring stream communities. Biological Conservation 176: 30-

650 38. doi.org/10.1016/.j.biocon.2014.04.029

651 Birk, S and Hering, D. 2006. Direct comparison of assessment methods using benthic 652 macroinvertebrates: a contribution to the EU Water Framework Directive intercalibration exercise 653 Hydrobiologia 566: 401. doi:10.1007/s10750-006-0081-8

654 Bogan, MT, Boersma, KS and Lytle, DA. 2015. Resistance and resilience of invertebrate communities 655 to seasonal and supraseasonal drought in arid-land headwater streams. Freshwater Biology. 656 doi: 10.1111/fwb.12522

657 Boulton, A J. 2003. Parallels and contrasts in the effects of drought on stream macroinvertebrate 658 assemblages. Freshwater Biology, 48: 1173-1185. doi: 10.1046/j.1365-2427.2003.01084.x

659 Boulton, AJ and Lake, PS. 2008. Effects of drought on stream insects and its ecological 660 consequences. In Aquatic Insects: Challenges to Populations. Lancaster J. Briers RA (Eds), pp. 81661 102. CABI, Oxfordshire. doi.org/10.1079/9781845933968.0081

662 Boulton, AJ, Datry, T, Kasahara, T, Mutz, M and Stanford, JD. 2010. Ecology and management of the 663 hyporheic zone: stream-groundwater interactions of running waters and their floodplains. Journal of 664 the North American Benthological Society, 29. 26-40.

665 Burnham, KP and Anderson, DR. 2002. Model Selection and Multi-model Inference: A Practical 666 Information-theoretic Approach. Springer-Verlag, New York.

667 Caruso 2002. http://www.sciencedirect.com/science/article/pii/S0022169401005467

668 Chester, ET and Robson, BJ. 2011. Drought refuges, spatial scale and recolonisation by invertebrates 669 in non-perennial streams. Freshwater Biology. 56: 2094-2104. doi: 10.1111/j.1365$670 \quad 2427.2011 .02644 . x$

671 Chadd, R and Extence, C. 2004. The conservation of freshwater macroinvertebrate populations: a 672 community-based classification scheme. Aquatic Conservation: Marine and Freshwater Ecosystems, 673 14: 597-624. doi: 10.1002/aqc.630

674 Chadd, RP. 2010. Assessment of Aquatic Invertebrates. In Conservation Monitoring in Freshwater 675 Habitats, Hurford C, Schneider M, Cowx I (eds). Springer: Netherlands; 63-72. ISBN 978-1-4020$676 \quad 9278-7$

677 Chessman, B. 2015. Relationships between lotic macroinvertebrate traits and responses to extreme 678 drought. Freshwater Biology 60: 50-63.

679 Clews, E and Ormerod, SJ. (2009), Improving bio-diagnostic monitoring using simple combinations of 680 standard biotic indices. River Res. Applic., 25: 348-361. doi:10.1002/rra.1166

681 Dai, A. 2011 Drought under global warming: a review. WIREs Clim Change. 2: 45-65. doi: $68210.1002 /$ wcc.81 
Datry, T. 2012 Benthic and hyporheic invertebrate assemblages along a flow intermittence gradient: effects of duration of dry events. Freshwater Biology, 57 563-584

685 Datry, T, Larned, ST, Fritz, KM, Bogan, MT, Wood, PJ, Meyer, El and Santos, AN. 2014. Broad-scale patterns of invertebrate richness and community composition in temporary rivers: effects of flow intermittence. Ecography, 37. 94-104.

Dewson, ZS, James, ABW and Death, RG. 2007. A review of the consequences of decreased flow for instream habitat and macroinvertebrates. Journal of the North American Benthological Society 26: 401-415.

691 Dokulil, MT. 2016. Climate impacts on ecohydrological processes in aquatic systems, Ecohydrology \& Hydrobiology, Volume 16, Issue 1, 66-70, ISSN 1642-3593, dx.doi.org/10.1016/j.ecohyd.2015.08.001.

Dunbar, MJ, Pedersen, ML, Cadman, D, Extence, C, Waddingham, J, and Chadd, RP. 2010a. River discharge and local-scale physical habitat influence macroinvertebrate LIFE scores. Freshwater Biology 55:226-42. doi: 10.1111/j.1365-2427.2009.02306.x

Dunbar, MJ, Warren, M, Extence, CA, Baker, L, Cadman, D, Mould DJ, Hall, J and Chadd RP. 2010b. Interaction between Macroinvertebrates, Discharge and Physical Habitat in Upland Rivers. Aquatic Conservation: Marine and Freshwater Ecosystems, 20: S31-S44. doi: 10.1002/aqc.1089.

Extence CA. 1981. The effect of drought on benthic communities in a lowland river. Hydrobiologia 83,

700 217-224.

Extence CA, Balbi DM and Chadd, RP. 1999. River flow indexing using British benthic macroinvertebrates: a framework for setting hydroecological objectives. Regulated Rivers: Research and. Management, 15, 543-574 DOI: 10.1002/(SICI)1099-1646(199911/12)15:6<545::AIDRRR561>3.0.CO;2-W

705

706

707

708

709

710

711

712

713

714

715

716

717

718

719

720

721

722

723

724

Extence CA, Chadd RP, England J, Dunbar MJ, Wood PJ and Taylor ED. 2011. The assessment of fine sediment accumulation in rivers using macro-invertebrate community response. River Research and Applications. 29: 17-55. doi: 10.1002/rra.1569

Extence, CA, Chadd, RP, England, J and Naura, M. In press. Application of the Proportion of Sediment-sensitive Invertebrates (PSI) Biomonitoring index at local and national scales.

Furse MT, Wright JF, Armitage PD and Moss D. 1981. An appraisal of pond-net samples for biological monitoring of lotic macro-invertebrates. Water Research, 15: 679-689 doi.org/10.1016/00431354(81)90160-3

Grueber, CE, Nakagawa, S, Laws, RJ and Jamieson IG. 2011. Multimodel inference in ecology and evolution: challenges and solutions. Journal of Evolutionary Biology, 24:699-711.

Henriques, C, Garnett, K, Weatherhead, EK, Lickorish, FA, Forrow, D and Delgado, J. 2015. The future water environment - Using scenarios to explore the significant water management challenges in England and Wales to 2050, Science of The Total Environment, 512-513, Pages 381-396, ISSN 0048-9697, doi.org/10.1016/j.scitotenv.2014.12.047.

Humphries P, and Baldwin DS. 2003. Drought and aquatic ecosystems: an introduction. Freshwater Biology, 48: 1141-1146. doi: 10.1046/j.1365-2427.2003.01092.x

James ABW, and Suren AM. 2009. The response of invertebrates to a gradient of flow reduction-an instream channel study in a New Zealand lowland river. Freshwater Biology, 54: 2225-2242. DOI:10.1111/ j.1365-2427.2009.02254.x. 
Kath J, Harrison E, Kefford, BJ, Moore, L, Wood, PJ, Schäfer, RB and Dyer F. 2016. Looking beneath

726 the surface: using hydrogeology and traits to explain flow variability effects of stream 727 macroinvertebrates. Ecohydrology, 9: 1480 - 1495.

728 Lake PS. 2000. Disturbance, patchiness, and diversity in streams. Journal of the North American.

729 Benthological Society, 19: 573-592.

730 Lake PS. 2003. Ecological effects of perturbation by drought in flowing waters. Freshwater Biology, 731 48: 1161-1172. doi: 10.1046/j.1365-2427.2003.01086.x

732 Lake PS. 2011. Drought and Aquatic Ecosystems: Effects and Responses. Wiley-Blackwell ISBN: 733 978-1-4051-8560-8

734 Ledger, ME and Milner AM. 2015. Extreme events in running waters. Freshwater Biology, 60: 24557352460.

Leigh, C, Boulton, AJ, Courtwright, JL, Fritz, K, May, CL, Walker, RH and Datry, T. 2015. Ecological research and management of intermittent rivers: an historical review and future directions. Freshwater

738 Biology, doi: 10.1111/fwb.12646

739 Leigh, C, Bonanda, N, Boulton, AJ, Hugueny, B, Larned, ST, Vander Vorste, R and Datry, T. 2016.

740 Invertebrate assemblage responses and the dual roles of resistance and resilience to drying in

741 intermittent rivers. Aquatic Sciences 78: 291-301

742 Lu X, Gray C, Brown LE, Ledger ME, Milner AM, Mondragón RJ, Woodward G, and Ma A. 2016. 743 Drought rewires the cores of food webs, Nature Climate Change, ISSN: 1758-678X Accessed 20 744 August 2016

745 Mainstone CP. 1999. Chalk rivers: nature conservation and management. WRc Medmenham

746 Monk WA, Wood P J, Hannah DM, Wilson DA, Extence CA and Chadd RP. 2006. Flow variability and 747 macroinvertebrate community response within riverine systems River Research and Applications, 22: 748 595-615. doi: 10.1002/rra.933

749 Monk WA, Wood PJ, Hannah DM and Wilson DA. 2008. Selection of river flow indices for the 750 assessment of hydroecological change. Regulated Rivers: Research and. Management, 23: 113-122.

751 DOI: $10.1002 /$ rra.964

Monk WA, Wood PJ, Hannah DM, Extence CA, Chadd RP and Dunbar MJ. 2012. How does macroinvertebrate taxonomic resolution influence ecohydrological relationships in riverine ecosystems. Ecohydrology, 5, 36-45. doi: 10.1002/eco.192

Murray-Bligh JAD, Furse MT, Jones FH, Gunn RJM, Dines RA and Wright JF. 1997. Procedure for collecting and analysing macroinvertebrate samples for RIVPACS. Institute of Freshwater Ecology \& Environment Agency, 155pp ISO 10870 (2012) Water quality -- Guidelines for the selection of sampling methods and devices for benthic macroinvertebrates in fresh waters.

Orr HG, Johnson MF, Wilby RL, Hatton-Ellis T and Broadmeadow S. 2015. What else do managers 760 need to know about warming rivers? A United Kingdom perspective. WIREs Water, 2: 55-64. doi: $761 \quad 10.1002 /$ wat2.1062 characterisation. Progress in Physical Geography, 40, 743-767. DOI: 10.1177/0309133316652801 

Responses of fish and invertebrates to floods and droughts in Europe. Ecohydrology DOI: 10.1002/eco.1793

Pickwell, AGG. 2012. Development of a novel invertebrate indexing tool for the determination of salinity in aquatic inland drainage channels. MPhil Thesis, University of Lincoln.

770 Prudhomme, C, Giuntoli, I, Robinson, EL, Clark, DB, Arnell, NW, Dankers, R, Fekete, BM, Frassen, 771 W, Gerten, D, Gosling, SM, Hagemannd, S, Hannah, DM, Kim, H, Masaki, Y, Satoh, Y, Stake, T, 772 Wada, Y and Wisser, D. 2014. Hydrological droughts in the 21st century, hotspots and uncertainties 773 from a global multimodel ensemble experiment. Proceeding of the National Academy of the Sciences 774 of the United States of America, 111(9): 3262-3267 doi: 10.1073/pnas.1222473110

775 Reich, P. and Lake, PS. 2014. Extreme hydrological events and the ecological restoration of flowing waters. Freshwater Biology. Advance Access June 2015 doi: 10.1111/fwb.12508

777 Rose, P, Metzeling, L and Catzikiris, S. 2008. Can macroinvertebrate rapid bioassessment methods 778 be used to assess river health during drought in south eastern Australian streams? Freshwater 779 Biology, 53: 2626-2638. doi:10.1111/j.1365-2427.2008.02074.x

Schmidt-Kloiber A and Hering D. 2015. www.freshwaterecology.info - An online tool that unifies, standardises and codifies more than 20,000 European freshwater organisms and their ecological preferences. Ecological Indicators, 53: 271-282

Smith, H, Wood, P and Gunn, J. 2003. The influence of habitat structure and flow permanence on invertebrate communities in karst spring systems. Hydrobiologia

510: 53. doi:10.1023/B:HYDR.0000008501.55798.20

Stubbington, R and Datry, T. 2013. The macroinvertebrate seedbank promotes community persistence in temporary rivers across climate zones. Freshwater Biology, 58: 1202-1220. doi: 10.1111/fwb.12121

Stubbington R, Greenwood AM, Wood PJ, Armitage PD, Gunn J and Robertson AL. 2009. The response of perennial and temporary headwater stream invertebrate communities to hydrological extremes. Hydrobiologia 630:299-312 10.1007/s10750-009-9823-8 composition in benthic and hyporheic zones during a severe supraseasonal drought. Freshwater Science 34, (1): 344-354.

Stubbington, R, Gunn, J, Little, S, Worrall, TP and Wood, PJ. 2016. Macroinvertebrate seedbank composition in relation to antecedent duration of drying and multiple wet-dry cycles in a temporary stream. Freshwater Biology, 61: 1293-1307. doi:10.1111/fwb.12770

Townsend CR and Hildrew AG. 1994. Species traits in relation to a habitat templet for river systems. Freshwater Biology 31: 265-275. doi: 10.1111/j.1365-2427.1994.tb01740.x

800 Turley, MD, Bilotta, GS, Chadd, RP, Extence, CA, Brazier, RE, Burnside, NG, Pickwell, AGG. 2016. A 801 sediment-specific family-level biomonitoring tool to identify the impacts of fine sediment in temperate 802 rivers and streams, Ecological Indicators, 70, 151-165, doi.org/10.1016/j.ecolind.2016.05.040.

803 Turley, MD, Bilotta, GS, Extence, CA and Brazier, RE. 2014. Evaluation of a fine sediment 804 biomonitoring tool across a wide range of temperate rivers and streams. Freshwater Biology, 59: 805 2268-2277. doi:10.1111/fwb.12429 
806 Van Loon, AF, Gleeson, T, Clark, J, Van Dijk, AlJM, Stahl, K, Hannaford, J, Di Baldassare, G, 807 Teuling, AJ, Tallaksen, LM, Uijlenhoet, R, Hanna, DM, Sheffield, J, Svoboda, M, Verbeiren, B, 808 Wagener, T, Rangecroft, S, Wanders, N and Van Lanen, HAJ. 2016. Drought in the Anthropocene. 809 Nature Geoscience 9, 89-91. doi:10.1038/ngeo2646

810 Verdonschot, RCM, van Oosten-Siedlecka, AM, ter Braak, CJF and Verdonschot, PFM. 2015. 811 Macroinvertebrate survival during cessation of flow and streambed drying in a lowland stream. 812 Freshwater Biology, 60: 282-296. doi:10.1111/fwb.12479

813 Vilmi, A, Karjalainen, SM, Nokela, T, Tolonen, KT and Heino, J. 2015. Unravelling the drivers of 814 aquatic communities using disparate organismal groups and different taxonomic levels. Ecological 815 Indicators 60: 108-118

816 Watts G and Anderson M (eds.). 2013. A climate change report card for water. LWEC report 817 card. http://www.Iwec.org.uk/book/export/html/1591 Accessed 10 June 2016

818 Watts, G, Battarbee, RW, Bloomfield, JP, Crossman, J, Daccache, A, Durance, I, Elliott, JA, Garner, 819 G, Hannaford, J, Hannah, DM, Hess, T, Jackson, CR, Kay, AL, Kernan, M, Knox, J, Mackay, J, 820 Monteith, DT, Ormerod, SJ, Rance, J, Stuart, ME, Wade, AJ, Wade, SD, Weatherhead, K, Whitehead, 821 PG and Wilby, RL. 2015. Climate change and water in the UK - past changes and future prospects. 822 Progress in Physical Geography. 39. 6-28.

823 Wilby, RL, Orr, H, Watts, G, Battarbee, RW, Perry, PM, Chadd, R, Dugdale, SJ, Dunbar, MJ, Elliott, $824 \mathrm{JA}$, Extence, C, Hannah, DM, Holmes, N, Johnson, AC, Knights, B, Milner, NJ, Ormerod, SJ, 825 Solomon, D, Timlett, R, Whitehead, PJ, and Wood, PJ. 2010. Evidence needed to manage freshwater 826 ecosystems in a changing climate: turning adaptation principles into practice. Science of the Total 827 Environment 408: 4150-4164. doi.10.1016/i.scitotenv.2010.05.014

828 Wood, PJ and Armitage, PD. 2004. The Response of the Macroinvertebrate Community to Low-Flow 829 Variability and Supra- Seasonal Drought within a Groundwater Dominated Stream. Archiv für 830 Hydrobiologie, 161: 1-20. DOI: 10.1002/hyp.7290

831 Wood, PJ and Petts, GE. 1994. Low flows and recovery of macroinvertebrates in a small regulated 832 chalk stream. Regulated Rivers: Research and. Management, 9: 303-316. 833 doi:10.1002/rrr.3450090410

834 Wood, PJ, Agnew, MD and Petts. GE. 2000. Flow variations and macroinvertebrate community 835 responses in a small groundwater-dominated stream in south-east England. Hydrological Processes 836 14: 3133-3147.

837 Zalewski, M. 2014. Ecohydrology, biotechnology and engineering for cost efficiency in reaching the 838 sustainability of biogeosphere. Ecohydrology and Hydrobiology, 14, 14-20. 


\section{Supplementary material: references used to assign DIS weights.}

842 Much of the weighting process was informed by personal communication with Andrew Boulton, using 843 work already carried out in Australia by him and Sam Lake. Adaptation of the weights for UK use was

844 undertaken using the reference material below.

845 Askew, RR. 1998. The Dragonflies of Europe. Harley Books, Colchester, UK.

846 Bass, J. 1998. Last Instar Larvae and Pupae of the Simuliidae of Britain and Ireland. FBA Scientific 847 Publication. No 55. FBA, Ambleside, UK.

848 Bauernfeind, E and Soldán, T. 2012. The Mayflies of Europe. Apollo Books, Ollerup.

849 Buffagni, A, Cazzola, M, López-Rodríguez, MJ, Alba-Tercedor, J and Armanini, DG. 2009. Distribution 850 and Ecological Preferences of European Freshwater Organisms. Volume 3: Ephemeroptera. Pensoft, 851 Sofia and Moscow.

852 Chandler, PJ (Ed.). 2010. A Dipterist's Handbook. The Amateur Entomologists' Society, Orpington, 853 UK

854 Corbet, P \& Brooks, S. 2008. New Naturalist Volume 106: Dragonflies. Harper-Collins, London.

855 Cranston, PS, Ramsdale, CD, Snow, KR and White, GB. 1987. Adults, Larvae and Pupae of British 856 Mosquitoes (Culicidae). FBA Scientific Publication. No 48. FBA, Ambleside, UK.

857 Dijkstra, K-D and Lewington, R. 2006. Field Guide to the Dragonflies of Britain and Europe. British 858 Wildlife Publishing, Gillingham, UK.

859 Dillon, RT Jr. 2000. The Ecology of Freshwater Molluscs. Cambridge University Press.

860 Disney, RHL. 1999. British Dixidae (Meniscus Midges) and Thaumaleidae (Trickle Midges). FBA 861 Scientific Publication. No 56. FBA, Ambleside, UK.

862 Edington, JM, Hildrew, AG. 1995. Caseless Caddis Larvae of the British Isles. A key with ecological 863 notes. FBA Scientific Publication. No 53. FBA, Ambleside, UK.

864 Elliott, JM. 2009. Freshwater Megaloptera and Neuroptera of Britain and Ireland. FBA Scientific 865 Publication. No 65. FBA, Ambleside, UK.

866 Elliott, JM and Humpesch, UH. 2010. Mayfly Larvae (Ephemeroptera) of Britain and Ireland. FBA 867 Scientific Publication. No 66. FBA, Ambleside, UK.

868 Ellis, AE. 1978. British Freshwater Bivalve Mollusca. Synopsis of the British Fauna. No.11. Academic 869 Press, London.

870 Fitter, R, Manuel, R. 1986. Collins Field Guide to Freshwater Life. Collins, London.

871 Foster, GN, Bilton, DT and Friday, LE. 2011. Keys to the Adults of the Water Beetles of Britain and 872 Ireland (Part 1: Hydradephaga). Royal Entomological Society, St Albans, UK.

873 Foster, GN and Friday, LE. 2014. Keys to the Adults of the Water Beetles of Britain and Ireland (Part 874 2: Hydrophiloidea). Royal Entomological Society, St Albans, UK.

875 Gledhill, T, Sutcliffe, DW and Williams, WD. 1993. British Freshwater Crustacea Malacostraca. FBA

876 Scientific Publication. No 52. FBA, Ambleside, UK 
877 Gooderham, J and Tsyrlin, E. 2002. The Waterbug Book: A Guide to the Freshwater 878 Macroinvertebrates of Temperate Australia. CSIRO Publishing, Collingwood, Australia.

879 Graf, W, Murphy, J, Dahl, J, Zamora Muñoz, C and López-Rodríguez, MJ. 2008. Distribution and 880 Ecological Preferences of European Freshwater Organisms. Volume 1: Trichoptera. Pensoft, Sofia 881 and Moscow.

882 Graf, W, Lorenz, AW, Tierno de Figueroa, JM, Lücke, S, López-Rodríguez, MJ and Davies, C. 2009. 883 Distribution and Ecological Preferences of European Freshwater Organisms. Volume 2: Plecoptera. 884 Pensoft, Sofia and Moscow.

885 Hynes, HBN. 1984. Adults \& Nymphs of British Stoneflies (Plecoptera). A key. FBA. Scientific 886 Publication No. 17. FBA, Ambleside, UK

887 Janus, H. 1982. The Illustrated Guide to Molluscs. Harold Starke Ltd, London.

888 Kerney, M. 1999. Atlas of the Land and Freshwater Molluscs of Britain and Ireland. Harley Books, 889 Colchester.

890 Kreyszig, E. 1979. Advanced Engineering Mathematics (Fourth ed.). Wiley, UK.

891 Killeen, I, Aldridge, D and Oliver, G. 2004. Freshwater Bivalves of Britain and Ireland. Field Studies 892 Council, Shrewsbury, UK.

893 Macadam, C and Bennett, C. 2010. A Pictorial Guide to British Ephemeroptera. Field Studies Council, 894 Shrewsbury, UK.

895 Reynoldson, TB and Young, JO. 2000. A Key to the Freshwater Triclads of Britain and Ireland. FBA 896 Scientific Publication. No 58. FBA, Ambleside, UK.

897 Savage, AA. 1989. Adults of the British Aquatic Hemiptera Heteroptera. FBA Scientific Publication. No 898 50. FBA, Ambleside, UK.

899 Stubbs, A and Drake, M. 2014. British Soldierflies and their Allies. British Entomological and Natural 900 History Society, Reading, UK.

901 Waringer, J and Graf, W. 2011. Atlas der Mitteleuropäischen Köcherfliegenlarven. Erik Mauch Verlag, 902 Dinkelscherben.

903 Wallace, I. 2010. Notes on the identification of China-mark larvae in The Identification of Freshwater 904 Invertebrates to Species Level: a Distance learning Course, Module 9, Miscellaneous Taxa. Chadd, 905 R. (Ed.), Environment Agency of England and Wales, Bristol, UK.

906 Wallace, I.D, Wallace, B, Philipson GN. 1990. A key to the case bearing Caddis Larvae of Britain and 907 Ireland. F.B.A. Scientific Publication. No 51. Ambleside, UK. 


\section{Supplementary material: references used to assign DIS weights.}

Much of the weighting process was informed by personal communication with Andrew Boulton, using work already carried-out in Australia. Adaptation of the weights for UK use was, however, undertaken using the reference material below.

Askew, R.R. 1998. The Dragonflies of Europe. Harley Books, Colchester, UK.

Bass, J. 1998. Last Instar Larvae and Pupae of the Simuliidae of Britain and Ireland. FBA Scientific Publication. No 55. FBA, Ambleside, UK.

Bauernfeind, E. and Soldán, T. 2012. The Mayflies of Europe. Apollo Books, Ollerup.

Buffagni, A., Cazzola, M., López-Rodríguez, M. J., Alba-Tercedor, J. and Armanini, D.G. 2009.

Distribution and Ecological Preferences of European Freshwater Organisms. Volume 3:

Ephemeroptera. Pensoft, Sofia and Moscow.

Chandler, P.J. (Ed.) 2010. A Dipterist's Handbook. The Amateur Entomologists' Society, Orpington, UK.

Corbet, P \& Brooks, S. 2008. New Naturalist Volume 106: Dragonflies. Harper-Collins, London.

Cranston, P.S., Ramsdale, C.D., Snow, K.R. and White, G.B. 1987. Adults, Larvae and Pupae of British Mosquitoes (Culicidae). FBA Scientific Publication. No 48. FBA, Ambleside, UK.

Dijkstra, K-D and Lewington, R. 2006. Field Guide to the Dragonflies of Britain and Europe. British Wildlife Publishing, Gillingham, UK.

Dillon, R.T. Jr. 2000. The Ecology of Freshwater Molluscs. Cambridge University Press.

Disney, R. H. L. 1999. British Dixidae (Meniscus Midges) and Thaumaleidae (Trickle Midges). FBA Scientific Publication. No 56. FBA, Ambleside, UK.

Edington, J.M., Hildrew, A.G. 1995. Caseless Caddis Larvae of the British Isles. A key with ecological notes. FBA Scientific Publication. No 53. FBA, Ambleside, UK.

Elliott, J.M. 2009. Freshwater Megaloptera and Neuroptera of Britain and Ireland. FBA Scientific Publication. No 65. FBA, Ambleside, UK.

Elliott, J.M. and Humpesch, U.H. 2010. Mayfly Larvae (Ephemeroptera) of Britain and Ireland. FBA Scientific Publication. No 66. FBA, Ambleside, UK.

Ellis, A.E. 1978. British Freshwater Bivalve Mollusca. Synopsis of the British Fauna. No.11. Academic Press, London.

Fitter, R., Manuel, R. 1986. Collins Field Guide to Freshwater Life. Collins, London.

Foster, G.N., Bilton, D.T. and Friday, L.E. 2011. Keys to the Adults of the Water Beetles of Britain and Ireland (Part 1: Hydradephaga). Royal Entomological Society, St Albans, UK.

Foster, G.N. and Friday, L.E. 2014. Keys to the Adults of the Water Beetles of Britain and Ireland (Part 2: Hydrophiloidea). Royal Entomological Society, St Albans, UK.

Gledhill, T., Sutcliffe, D.W. and Williams, W.D. 1993. British Freshwater Crustacea Malacostraca. FBA Scientific Publication. No 52. FBA, Ambleside, UK

Gooderham, J. and Tsyrlin, E. (2002): The Waterbug Book: A Guide to the Freshwater Macroinvertebrates of Temperate Australia. CSIRO Publishing, Collingwood, Australia.

Graf, W., Murphy, J., Dahl, J., Zamora Muñoz, C. and López-Rodríguez, M. J. (2008): Distribution and Ecological Preferences of European Freshwater Organisms. Volume 1: Trichoptera. Pensoft, Sofia and Moscow. 
Graf, W., Lorenz, A.W., Tierno de Figueroa, J.M., Lücke, S., López-Rodríguez, M. J. and Davies, C. (2009): Distribution and Ecological Preferences of European Freshwater Organisms. Volume 2: Plecoptera. Pensoft, Sofia and Moscow.

Hynes, H.B.N. 1984. Adults \& Nymphs of British Stoneflies (Plecoptera). A key. FBA. Scientific Publication No. 17. FBA, Ambleside, UK

Janus, H. 1982. The Illustrated Guide to Molluscs. Harold Starke Ltd, London.

Kerney, M. 1999. Atlas of the Land and Freshwater Molluscs of Britain and Ireland. Harley Books, Colchester.

Killeen, I., Aldridge, D. and Oliver, G. 2004. Freshwater Bivalves of Britain and Ireland. Field Studies Council, Shrewsbury, UK.

Macadam, C. and Bennett, C. 2010. A Pictorial Guide to British Ephemeroptera. Field Studies Council, Shrewsbury, UK.

Reynoldson, T.B. and Young, J.O. 2000. A Key to the Freshwater Triclads of Britain and Ireland. FBA Scientific Publication. No 58. FBA, Ambleside, UK.

Savage, A. A. (1989): Adults of the British Aquatic Hemiptera Heteroptera. FBA Scientific Publication. No 50. FBA, Ambleside, UK.

Stubbs, A. and Drake, M. 2014. British Soldierflies and their Allies. British Entomological and Natural History Society, Reading, UK.

Waringer, J. and Graf, W. (2011): Atlas der Mitteleuropäischen Köcherfliegenlarven. Erik Mauch Verlag, Dinkelscherben.

Wallace, I. 2010. Notes on the identification of China-mark larvae in The Identification of Freshwater Invertebrates to Species Level: a Distance learning Course, Module 9, Miscellaneous Taxa. Chadd, R. (Ed.), Environment Agency of England and Wales, Bristol, UK.

Wallace, I.D., Wallace, B., Philipson G.N. 1990. A key to the case bearing Caddis Larvae of Britain and Ireland. F.B.A. Scientific Publication. No 51. Ambleside, UK. 